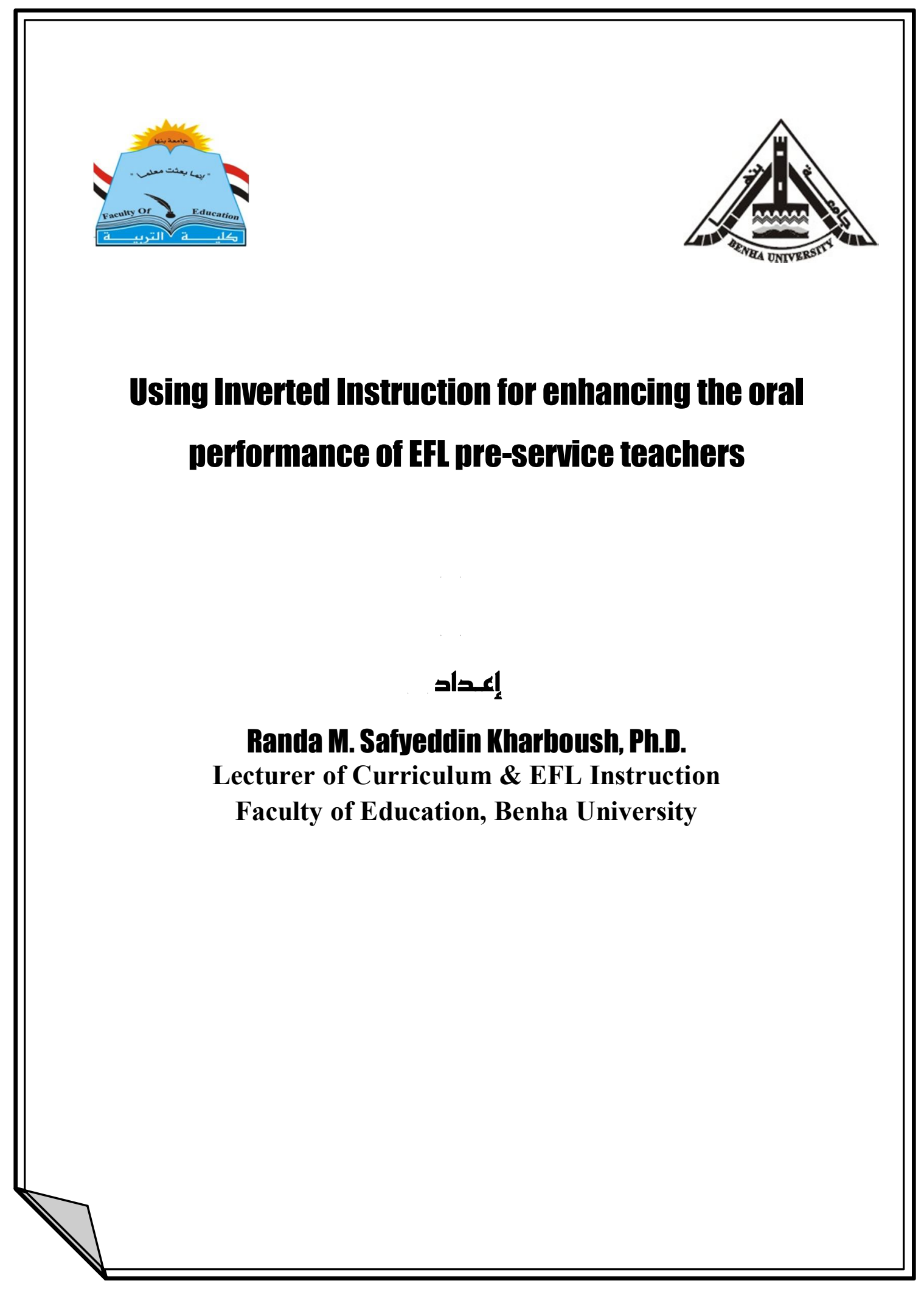




\title{
Using Inverted Instruction for enhancing the oral performance of EFL
} pre-service teachers

\author{
إعـداد
}

\section{Randa M. Safyeddin Kharboush, Ph.D.}

Lecturer of Curriculum \& EFL Instruction

Faculty of Education, Benha University

يحرص التربويون والمهتمون بالتعليم في مجال تدريس اللغة الاجليزية على استثمار الابتكارات التكنولوجية لتحسين العملية التعليمية و خلق نماذج واستر اتيجيات مستحدثة فعالة للتعليم والتعلم. ومن بين هذه النماذج التي تعتمد بثكل كبيرعلى توظيف التكنولوجيا نموذج التعليم المعكوس أو المقلوب أو ولئولئه الصف الاراسي المعكوس، ولقد حظي هذا النموذج بالكثير من الاهتمام على جميع المستويات في مختلف أنحاء العالم، وذلك لحداثته وجدة الفكرة التي يقوم عليها حيث يقوم الطالب بدراسة المحتوى الارسي من خلال فيديو هات تعليمية ومحاضرات مسجلة مسبقا بالاضافة الى القراعات المكلف بها وذلك قبل حضوره الى الصف الار اسي التي يتم تكريس معظم الوقت المخصص له في المناقثات و التدريبات العملية وممارسة الأشطة التعليمية المختلفة، وهذا من شأنه إتاحة فرص عديدة للمعلم والطلاب للتفاعل المثمر والتواصل اللغوي مما يساعد على تنمية المهارات اللغوية والكفاءة التواصلية للطالب في مناخ صحي مهيأ لتعزيز الأداء اللغوي للطالب. وقد هدفت الدراسة الحالية الى استخدام نموذج التعليم المعكوس في تحسين وتعزيز الأداء الثفهي للطلاب المعلمين بشعبة اللغة الإجليزية ـ تكونت عينة الدراسة من ^^ من طلاب برنامج

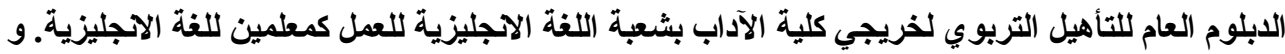
أظهرت النتائج الاحصائية تفوق أفراد المجموعة التجريبية على أفراد المجموعة الضابطة في الأداء الثفهي للغة الاجليزية بأبعاده الأربعة :الطلاقة والاتساق اللغوي، الثروة المعجمية ، الاقة والقدرة النحوية، والنطق ومخارج الألفاظ. بينما كثفت الدراسة النوعية التحليلية عن تفهم الطلاب المشاركين لمفهوم التعليم المعكوس وتحمسهم له واقتناعهم بجدواه في تحسين مهاراتهم اللغوية وتعزيز أدائهم الثفهي للغة الانجليزية.

الكلمات المفتاحية : التعليم المعكوس - الصف الدر اسي المقلوب ـ تدريس اللغة الانجليزية كلغة أجنبية تعزيز الأداء الثفهي - الطلاب المعلمين بشعبة اللغة الانجليزية 


\section{Ahstract}

The inverted instruction (II) as a pedagogical model has recently gained more recognition and commendation and become one of the most noteworthy innovative instructional models in education, where students watch instructional videos and read assigned materials outside/before the classroom and engage in productive tasks and activities inside/during the classroom. In foreign language (FL) teaching, the II may offer great benefits for both teachers and students by providing more interactive tasks that can help to enhance learners' language skills. In this context, the researcher deployed II to explore its impact on enhancing EFL pre-service teachers' $(\mathrm{N}=88)$ oral performance. A pre- and post-test quasiexperimental design, with control $(\mathrm{N}=45)$ and experimental $(\mathrm{N}=43)$ groups, was utilized to achieve the purpose of the study. Quantitative data was collected, analyzed, and statistically treated using SPSS. Statistical analysis of results revealed that the experimental group participants outperformed the control group participants, and there were statistically significant differences at 0.00 level between the two groups at the end of an eight-week intervention process using II. The findings of the study also indicated that the experimental group participants developed significantly in the four measured dimensions of oral performance: fluency and coherence, lexical resource, grammatical range and accuracy, and pronunciation. The researcher supported her quantitative results with qualitative data collected to gain insights into the participants' perceptions of the newly used model and their reflections on II. The results revealed that the EFL pre-service teacher participants had a positive attitude towards the use of II as a constituent part of their study courses. The study also provided recommendations for II's implementation and integration into courses in other EFL teaching.

Keywords: Inverted instruction; flipped classroom; teaching English as a foreign language; oral performance enhancement; pre-service teachers. 


\section{Introduction}

In most EFL classrooms, the instructor is the "sage on the stage"; the one who has all the knowledge and transmits it, the one who lectures and students listen and take notes. This traditional teacher-fronted instruction often breeds passive learners. The old world pedagogy model that sees the instructor as the central figure is outdated and is not adequate for the 21 st century, as individuals think for themselves, argue, criticize, solve complex problems and create solutions. Therefore, there is a growing need to rethink and redesign new instructional models ample for the $21^{\text {st }}$-century classroom. In contrast to the transmittal model, the constructivist one emerged to place the students at the center of the whole process, actively participating, critically-thinking, and creatively coming up with innovative ideas. These students participate in the instructional process, and the instructor, instead of being the sage on the stage, functions as a guide on the side, facilitating active collaborative engagement with learning resources for the students in fewer directive ways.

The advance in digital technologies provides many opportunities for students to learn in a more dynamically and innovatively. The concept of blended learning represents one of the breakthroughs in the last half-century. This modern educational approach is a hybrid from the application of a variety of technologies and the traditional lecture, and based on that model the inverted instruction (II) as one in this vein, appeared as a pedagogy-first approach to teaching, including teaching English as a foreign language (TEFL). It combines untraditional knowledge transfer before class and various activities in class.

Educators have been trying to improve teaching delivery methods through employing innovative models, such as II, and make use of its tactics. Such pedagogy, which consists of a combination of pre-class and in-class learning activities, has been promoted to encourage students to learn more dynamically and innovatively and drive them to become more responsive and engaged in the learning process. In-class time can thus be freed up for students to deepen their understanding of the content through group problem-solving, research assignments, demonstrations, experiments, discussions, and other engaging experiences. Inverted instruction, or flipped instruction (the two terms were used alternatively throughout the current research), involves assignments for the students to work through on their own time and at their own pace. Instead of listening to a traditional 
in-person lecture, the students often watch a recorded lecture, complete a guided reading, or do research assignments. In this approach, in-class time is devoted to inquiry, assessment, and application to better meet the individual differences between learners. During class time, the instructor facilitates the learning process by assisting the students through course materials individually and cooperatively in groups.

\section{Inverted instruction model (IIM)}

The notion of "inverted classroom" presented by Lage, Platt, and Treglia (2000) as they asserted that learning would be more interesting for students when it occurred not only inside but also outside the classroom. In 2007, the two science teachers, Bergmann and Sams, started using pre-recorded instructional videos and recognized how excited and motivated the students are in learning activities after watching the videos. They wrote a book together (2012), entitled "Flip your classroom: Reach every student in every class everyday," which guides other educators and teachers through flipping their classrooms as an alternative way to traditional lecture-based instruction.

Staker \& Horn, 2012 state that II is a form of blended learning in which students have control over 'time, place, path and pace' during their learning and actively participate in the instruction process (Hamdan, Mcknight, Mcknight, \& Arfstrom, 2013). It reinforces the idea that learning is not restricted to classroom walls. Lage, Platt, and Treglia (2000, p.32) defined II stating that "Inverting the classroom means that events that have traditionally taken place inside the classroom now take place outside the classroom and vice versa." So, inverted instruction pedagogy (IIP) is an overall term for the reverse traditional educational setting; is also referred to as "inverted classroom", "flipped classroom", "reverse instruction", "condensed classroom", "blended learning", "post-lecture classroom", or "24/7 classroom" (Bergmann \& Sams, 2012; Plasencia, 2014;).

The principle of II, the recently emerged innovative and popular technologyinjected learning model, is for instruction used to occur in class to be accessed at home in advance. Then in-class time can be freed up for students to participate in problem-solving and collaborative learning tasks under the guidance of the teacher to enhance the effectiveness of learning. The classroom turns out to be for working through problems and engaging in collaborative learning (Kim, Kim, Khera, \& Getman, 2014; Lage, Platt, \& Treglia, 2000; Tucker, 2012). 
Strayer (2007) defines II as an "innovative classroom structure that moves the lecture outside the classroom via technology and moves homework and practice with concepts inside the classroom via learning activities" (p. ii). See \& Conry (2014) claimed that II helped cognitive development and moved understanding and remembering, which are the low levels of Bloom's Taxonomy, outside the class, and fill in-class time with creating, evaluating, analyzing, and applying that are higher thinking skills.

In an inverted classroom, information transmission is moved out of class time and replaced by corresponding activities, collaborative tasks. Gannod (2007) defines II, as the name suggests, as diverted forms of traditional lecture, and it uses technology to present course content in video-lecture format or online learning materials. Students may access course material as often as they need and reflect upon it while scaffolding, building more complicated concepts later as they advance. II facilitates opportunities for students and teachers to be partners in the learning process, whether online, face-to-face, or in hybrid/blended learning environments.

According to Educause (2012), instructors from around the globe have received the IIM with great enthusiasm and are utilizing it in all educational sectors. The IIM is utilizing technological assets, like the Internet, YouTube, Facebook, MySpace, and many other advanced assets, which fills in many significant gaps in the traditional instructional approach and provides learners with the edge in the era of digital transformation.

\section{Advantages of inverted instruction pedagogy}

Many scholars agreed that providing instructional content through untraditional channels, like videos, can free class time that is spent mostly in traditional lectures (Alvarez, 2011; Bergmann \& Sams, 2012; Gannod, 2007). Then valuable class time can be utilized for working productively with peers under the teacher's guidance. Instructional content is presented to the learners through videos to study by themselves at their own time and pace, and class time is used for practice, discussion, and evaluation. Learners actively and constructively participated in the learning processes as they turn into autonomous learners.

Several benefits of IIP can be counted as tangible evidence of its significant effects on educational progress for teachers and learners as well. As for teachers, they can pursue better teaching strategies and establish a healthy relationship with 
students when they flip their classrooms. Besides, teachers, with IIP, have more time to pay attention to their students' progress, their individual differences, and help them with any struggling issues. As Dewey (2013) stated, "The teacher is not in the school to impose certain ideas or to form certain habits in the child, but is there as a member of the community to select influences which shall affect the child and to assist him in properly responding to these influences" (p. 36). Teachers have enough time to prepare creative tasks, exciting activities, and challenging endeavors that suit their students' intellectual growth.

Bergmann and Sams (2012) claimed that it was such a fruitful experience for them to spend less time on delivering the content to the students and act in the classroom as a learning coach, in a learner-centered environment. Teachers found it more convenient to offer differential instruction based on students' needs and individual differences, which helped them learn better (Graham \& Walker, 2013).

\section{As for students, the IIM:}

- Offers a flexible mode of learning; since the learning materials can be accessed online, students have the autonomy to take control of their learning in their own space and at their own pace.

- Helps students to reinforce their understanding of the content knowledge. They are generally required to watch assigned online videos before class, then participate in group activities and discuss problems or misconceptions in class, and after class, encouraged to review the online learning materials provided and other resources on demand.

- Fosters students' self-regulation competence (Lai \& Hwang, 2016), digital literacy skills, and lifelong learning skills required in the 21 st century $(\mathrm{Ng}$, 2015).

- Facilitates using class time more effectively and creatively to provide multiple opportunities for students to collaborate and apply what they have learned.

- Assists students to explore instructional content independently by watching easily accessed videos at home/ any time, which they can rewind, pause, or rewatch if they want. It also fosters a deeper understanding of the knowledge gained, through the video, during classroom activities, and through discussions of issues they bring to class to resolve. 
- Boosts students' engagement and improve their performance (Clark, 2015; Millard, 2012; Stone, 2012; Walsh, 2013), as it sustains a learning environment conducive to accountability and meaningful learning experiences.

- Improves students' learning outcomes, assignment performance, motivation, levels of engagement, and satisfaction with the untraditional innovative learning in the classroom (Mason, Shuman, \& Cook, 2013; McLaughlin et al., 2013; Stone, 2012).

- Aids to raise test scores and elevate academic achievement (Evseeva \& Solozhenko, 2015; Goodwin \& Miller, 2013; Morgan, 2014; Yu \&Wang, 2016).

- Provides more capacity in class to develop students' critical thinking skills, problem-solving skills (Mason et al., 2013), creative thinking skills (Al-Zahrani, 2015), and collaborative learning skills (Strayer, 2012).

- Encourage students to monitor their own learning speed and turn them into active explorers who can enjoy knowledge's navigation.

- Supplies the students with the key point to construct their own meanings from learning experiences and applying the knowledge they acquire into real-life.

- Furnishes students with more chances to practice English language skills simultaneously, when they watch authentic videos, listen to native speakers, read assigned materials, write homework assignments, and speak with teachers and peers during active discussions and collaborative activities in the classroom.

- Motivates students to become more involved (Nanclares \& Rodríguez, 2016) and stimulate higher-order thinking skills (Alsowat, 2016).

- Affects "students' knowledge acquisition involving information communication, information accessibility, information stimulation, information interaction and information accumulation" (Newman, Kim, Lee, Brown, and Huston 2016) (p. 67).

- Presents students with various means to study instructional content as part of the preparation for class (Harris et al.2016), and class time is used for hands-on interactive activities to practice, apply and demonstrate to master the content learned before class.

Accordingly, the instructor and students as collaborative learners have opportunities for leveraging resources to achieve more during their time together, targeting the course content, and tackling areas of learners' weaknesses, as needed, to ensure a better grasp of the target content. The class now is not only for 
information, and learning is not limited with school walls anymore; instead, it is a blend of discussion, hands-on activities, group practical exercises, listening, speaking, and doing, where students and teacher both play an active role in the overall learning process. With II, learners can learn the content wherever and whenever they want, and they have the opportunity to learn it even if they miss the class for any reason (Bergman \& Sams, 2012). The learning process occurs in collaboration with peers, along with teachers' help and guidance, and learners are active constructors.

\section{Context of the problem}

For TEFL, II makes an enormous difference when students get actively involved in the learning process; as they are responsible for studying course contents independently through videos before going to class, and class time is devoted to practice different skills and interactive tasks, which helps students enjoy discovering their academic passion and future passage (Abeysekera \& Dawson, 2015; Berrett, 2012; Bishop \& Verlager, 2013; Fulton, 2012; Hung, 2015; Torkelson, 2012).

In the Egyptian educational setting, II has not been applied on a large scale, especially in TEFL, to the best knowledge of the researcher. The number of research papers on the implementation of II in the field of TEFL at the university level is also limited. Thus, this study aims to address this gap in the research library, besides there are some problems in the current situation of EFL teaching and learning in Egypt that researchers need to reflect upon.

- The first disappointing fact is the low level of English communicative competence of Egyptian students. After spending many years studying English from primary through secondary school and at the university level, most of them, and even graduates, cannot use the language to communicate efficiently in real-life situations.

- One of the serious consequences is that those graduates will not be able to find decent jobs, which may negatively affect their attitudes toward EFL learning.

- Even though many teachers may be aware of the modern trends of communicative TEFL, most of them cannot apply these teaching approaches successfully or find it easier to stick to content-based lectures as it is less time and effort consuming. 
- There is a lack of mutual interaction in the classroom, teacher- students' interaction, and peers' interaction too. In some cases, due to large class numbers, teachers are not able to interact with their students individually; consequently, they do not know much about their preferences, individual differences or their struggling issues

For EFL learners, their only chance to practice their language skills is with their teacher and peers, which makes it of utmost importance. However, students cannot exercise their communicative skills because they rarely have the chance to work in pairs or groups. Therefore, the teacher /researcher strived to find a better way for students to enhance their EFL oral performance effectively and enjoyably. Inverting the classroom might be an ample route to help students, as well as teachers, to attain their target goals.

\section{Review of related studies}

Many scholars claim that helps to build an interactive community in the classroom, and Strayer's study (2012) supported that when he commented on "How learning in an inverted classroom influences cooperation, innovation, and task orientation" (p. 171). He compared an inverted classroom and a traditional one instructed by the same professor. Freshman and sophomore college students in different majors were the study's participants. The results revealed that participants in the inverted classroom were more engaged in collaborative pair and group work; they learned to work within a team and developed some social skills during the learning process.

In the same line of thought, Snowden (2012) investigated teachers' perceptions of II, through interviewing eight teachers who used II in their classrooms, and the results showed that teachers have positive perceptions towards II. On the other side, Johnson (2013) focused on students' perceptions of II with students in three high school math classrooms where instruction was inverted. He strived to get a broader and more in-depth understanding of students' perceptions through both qualitative and quantitative research measures. He ended up with three primary reasons for students' preference of II: (1) they do less homework, (2) they enjoyed the learning environment, and (3) they benefitted from watching the video. Goodwin and Miller (2013) also contend that II environment is stimulating 
as there are more interactions between teacher and students, and among students themselves, which affect students' attitudes positively.

A realistic case of a flipped classroom was presented in Brunsell and Horejsi's (2013) where they introduced a teacher-researcher who used flipping techniques with his students, collected data during all classes and recognized how excited students were when they watched videos before class and finished the assignments together in classroom interactions. The teacher had more time to explain and clarify unclear or complicated concepts and apply differentiated instruction. Correa (2015) compared two pedagogical strategies; flipped classroom and the transformation of pedagogy. He claimed that they share common factors of learning time, accessibility, functioning knowledge, scaffolding, and learner autonomy. Despite its possible limitations, the flipping approach goes above and beyond as it helps learners to develop their critical thinking and move forward to critical reflection and applications. Obari and Lambacher (2015) proved a successful approach to flipping in terms of educational technology, using mobile tools.

Meanwhile, Evseeva and Solozhenko (2015) also provided evidence that II technology helps to enhance students' motivation and improve their academic performance. Zainuddin \& Halili (2016) claimed that the preference of flipping was due to the mutual cooperation between the instructor and the students, which expanded their trust and self-esteem. The instructor's role has changed from a moderator of substance to a learning mentor who facilitates investing more energy conversing with students. With II, the students succeed in building up their own particular community-oriented gatherings.

\section{Inverted instruction in the field of TEFL}

Research on II and its application in TEFL have flourished in the past few years. Communicative language teaching (CLT) has been applied in EFL classrooms since the 1980s; to encourage EFL learners to use language communicatively and to increase interactive tasks in EFL classroom, and many EFL teachers ask their students do some reading assignments before coming to class; however, this cannot be considered II. Inverting instruction empowers learners' language proficiency and enables teachers to accelerate their skills development through flexible activities and creative assignments instead of 
completing monotonous tasks in the traditional classroom. Eryaman\& Genc (2010) stated that II offered enough opportunities for learners to "actively construct new ideas or concepts based on prior knowledge and/or experience" (p. 534). II turned the classroom into a stage where the teacher is not a 'sage' anymore, but act as a guide/coach while students take the part of potential communicators in real-life situations and engage in the learning process.

Some studies investigated using II with writing skills; Engin (2014), for example, carried out research where he devised as part of a second language academic writing course. The aim was to encourage students' active participation in the learning process by following a model, research a topic, and craft a video tutorial on an aspect of academic writing. The results of the study showed that student-created videos promoted SL learning and accuracy in English. Meanwhile, Ekmekcci (2014) investigated the effects of II on EFL students' writing skills development in two ELT classes at School of Foreign Languages. The results revealed that using was more effective in developing students' writing skills than the traditional lecture-based one. Later, Qader \& Arslan (2019) tackled the effect of using II in writing with Iraqi EFL learners, and the findings indicated that the experimental group performed better than the control one in the writing tests. Additionally, the participants' attitudes towards II were mostly positive.

For investigating an implementation of, Basal (2015) collected qualitative data, and based on the content analysis of the participants' responses; he came up with four categories in which II was beneficial: learning at individual's own pace, advance learner's preparation, overcoming the limitations of class time, increasing active participation in the classroom. He affirmed the many benefits that bring to ELT teachers, "including videos of real-life situations where students can listen to native speakers and teachers could take advantage of ready-to-use rich content" ( $\mathrm{p}$. 35). Along the same line, Hung (2015) introduced a WebQuest active learning strategy, based on II, to enable her students to become explorers of knowledge. Results revealed that II based lessons were more interesting, engaging to English learners than the non-inverted ones. Learners had more opportunities to actively involve in acquiring the target knowledge and would become more responsible for the learning outcomes that motivated them to practice their language skills not only during their class time but also through life-like situations. 
In the meantime, Sung (2015) did a case study on II in EFL class in Korea, where 12 participating college students were to preview weekly readings or video, submit questions on an online platform, and join online discussions. Then, they did collaborative class activities, sharing their thoughts, discussing what they had done online, and doing a final project. Students viewed II as a positive experience despite the challenges they faced to adjust themselves to it. Moreover, they believed that II could be good momentum for the change and development of current EFL instruction. In the same year, Sletten (2015), in her Ph.D. dissertation, investigated self-regulated learning strategies (SRLS) with II, and its effects on students' perceptions and achievement. The study's purpose was examining the relationship between students' perceptions of II and their SRL behaviors, besides the impact of these variables on achievement, as well as exploring the effect of II experience on SRLS use and achievement. The regression analysis revealed that the students' perceptions positively predicts their use of several types of SRLS, but the relationship between student perceptions and achievement was not indicated. Rahman, Aris, Mohamed, and Zaid (2015) tested the effectiveness of II on secondary school students' achievement and proved it had a positive impact. They presented some suggestions for redesigning the prior learning process of the approach for factoring in the preparation/readiness aspect.

Later, Webb \& Doman (2016) had a mixed-method quasi-experimental design, with II as a typical example of technology integrated strategy, to evaluate learning outcomes using computer-assisted language learning (CALL), technologyenhanced language learning (TELL), and mobile assisted language learning (MALL), at two institutions in Macau, China, and the US. The results indicated that experimental groups gained more significant actual achievement, compared to the control groups, and that II empowered English learners with updated knowledge and proficiency. In the field of English for Academic Purposes (EAP) teaching, Soliman (2016) has examined the II pedagogy application throughout a 13-week semester, using a module that comprised three phases of pre-class tasks, in-class tasks, and after-class tasks. The results emphasized the efficiency of II in EAP classes.

Zhuochao (2017) had her M.A. study thesis to decide whether to use the II model with SL students of higher-level or not. She dealt with the advantages and challenges of using in a higher-level ESL classroom. She focused on the 
importance of considering students' performance and their feedback on their learning in the II environment. Meanwhile, Doman and Webb (2017), in a largescale experiment at the University of Macau, investigated II experience for Chinese university students studying English as a FL. The study provided insightful results about learners' attitudes in the areas of teaching approaches, integration of technology, and social and academic outcomes of learners' involvement in the learning process. Findings showed that students in II class had more positive attitudes towards language learning experience than those in the traditional class. Chilingaryan \& Zvereva (2017) examined the potential of II application in FLT and its advantages over other traditional approaches, among which were increase of responsibility and self-reliance for learners, individualized learning approach, time extension between teacher and students,

More recently, Dweikat \& Raba (2019) in their study aimed to investigate the perceptions of EFL teachers in the Palestinian context in addition to identifying the effect of gender, qualification, and experience on teachers' perceptions. The sample of the study consisted of 79 EFL teachers, and results showed that teachers' responses suggested a high level of perceptions, and there were no statistically significant differences due to gender, qualification, and experience. The qualitative results revealed that a group of participants was in favor of using but with mature students and after providing the required infrastructure. The other group was supporting the use of because it might add more responsibilities and tasks to the overloaded teachers, and it might distract students as well.

Vaezi et al. (2019) examined the impact of II on improving the listening performance of English language learners. The data analysis revealed that the II model proved to be significantly effective in improving the listening performance of the experimental groups. Bohota (2019), in her M.A. study, aimed at establishing how blending traditional classroom method and flipped classroom approach can enhance the efficiency of teaching and learning of the tertiary level students as well as teachers at EFL classroom in Bangladeshi context. She was selective and decided to use only the appropriate and suitable tactics of FCA depending on the students' proficiency level and the context. She also focused on developing the effectiveness of the teachers of tertiary level students by applying the flipped classroom approach combined with the traditional classroom method. Qualitative data and interviews were analyzed and discussed to recommend the 
possible ways of applying this approach in the Bangladeshi context. Yavuz \& Ozdemir (2019) discussed some associated factors about using the flipped classroom approach in the EFL context and compared it with the traditional teaching class.

In the Arab world, Al-Harbi and Ashumaimeri (2016) used II in teaching English grammar to examine its impact on EFL Saudi secondary school students' performances, perceptions, and attitudes toward learning English. The statistical analysis of the results showed that adopting II was beneficial in enhancing the students' grammar performances, but the difference between the experimental and control groups was not statistically significant. The qualitative data indicated that participants' attitudes towards using II in the EFL class were positive. Abu Bakar et al. (2018) explored the use of II in teaching grammar. The results indicated that II had a positive impact on students' confidence level and grammar knowledge. Besides, it was also apparent that it could strengthen the teacher-student rapport. Shotaro, Fumiya, and Haruyo (2018) applied II to teach EFL for Japanese junior high school students, to examine its effect on their performances, attitudes, and perceptions toward learning EFL. The results illustrated that II appeared to play a significant role in enhancing the students' grammar and speaking, and it also showed that both students' and teachers' attitudes towards using II in the EFL class were positive. Following the same track, Hashemifardnia, Namaziandost, and Shafiee (2018) investigated the effect of implementing II on Iranian junior high school students' reading comprehension. The findings revealed that the experimental group, using II, significantly outperformed the control group, using the traditional approach.

In the Egyptian context, Desouky (2019) has attempted to discover the effect of II model on FL Egyptian learners to reinforce studying English. The participants from English department in the faculty of Education were in two groups: an experimental group that used the II model with 80 learners, while the control group of 78 learners used the CLT approach. The results revealed that only the mean score of the final test was statistically significant, and the scores of the participants in the experimental group were higher on average than the scores of the participants in the control one. Despite this result, both surveys and teacher's notes expressed another point of view, showing that the participants in II classroom enjoyed learning English more and were keener on participating in the learning process than the control group. 


\section{Inverted instruction for developing speaking skills}

Many researchers investigated the impacts of II on students' English language skills, writing skills (Engin, 2014; Yu \& Wang, 2016), listening skills (Vaezi et al., 2019), grammar (Al-Harbi \& Alshumaimeiri, 2016). Nevertheless, there is a paucity of studies on oral language skills under the influence of the II model. Notably, there are few discussions on how or to what extent students' speaking develops when they join an EFL II classroom. There seems to be less empirical studies focusing on using IIM to improve students' speaking skills (Alkhoudary \& Alkhoudary, 2019, Li \& Suwanthep, 2017, Rahman et al., Singh et al., 2015, 2018, Wu et al., 2018, Yesilcinar, 2019, Zhang et al. 2014, 2016).

Some educators consider speaking the most robust element of learning English among the four language skills. Speaking skill is one of the essential components of EFL, and teaching and developing it is a controversial issue. Some changes need to take place in teaching speaking skills; EFL teachers should create more studentcentered classrooms where learning speaking is more personalized and collaborative. Having close relationships and personal cooperation between students and instructor, and between peer as well, could have a significant effect on developing speaking skills. The use of technology in teaching speaking skills could also enhance its components providing language learners more autonomous and constructivist learning paths. Since the presentation of the II demonstrated by Bergmann and Sams (2012), EFL instructors typically use quite some time of their class strolling around their students striving to help them speak English fluently and accurately.

Zhang, Du, Yuan, and Zhang (2016) researched the effectiveness of II in the English pronunciation course. The II mode participants' final exam scores were compared with those of the traditional teaching model. Qualitative data were collected through interviews that were carried out to investigate the students' attitudes towards the two teaching modes. The study concluded that II was more effective than the traditional one in teaching pronunciation.

In their study, Li and Suwanthep (2017) examined the effects of integrating to teach English speaking in an EFL context, in a 12 weeks quasi-experiment that was conducted with two groups of university students in Thailand. The experimental group received II on grammatical and lexical knowledge via online video lectures and spent class time doing constructive activities and role-plays to practice 
speaking skills. Meanwhile, the control group was taught the same content using traditional instruction, followed by pattern drills as speaking activities. The researchers employed speaking pre/post-tests, questionnaires, and interviews to collect data. The data collected showed that the experimental group scored higher in the speaking post-test than the control group, and the participants expressed positive, supportive opinions towards the implementation of II and constructive activities.

$\mathrm{Wu}$, Hsieh, and Yang (2018), following the same track, examined the effects of a personalized, constructivist II on EFL learners' idiomatic knowledge and oral proficiency. The participants were 40 English-major sophomores, and the results revealed that such a personalized had a powerful effect on motivating students, turning them into active learners, and enhancing their learning outcomes. Singh et al. (2018) in Malaysia, investigated the use of IIM for enhancing technical and vocational engineering and training (TVET) trainees' speaking skills. Qualitative data was collected using classroom observation, interviews, and document analysis. Findings revealed that using the unique, innovative instruction tools of II, using videos followed by constructive activities, created a positive atmosphere among the trainees. Utilizing such resources, like YouTube videos, guided them to dramatize their roles, and empowered their confidence and ability to engage with peers. The findings also supported the claim that IIM was effective in enhancing trainees' speaking skills.

In their study, Alkhoudary \& Alkhoudary (2019) examined the impact of II on ESL Omani secondary school students' speaking skills. The results revealed that the experimental group excelled in the control one, and also showed a positive attitude towards II as a learning strategy. Meanwhile, Yesilcinar (2019) inspected the impact of II on adult Turkish EFL learners' speaking skills, using both qualitative and quantitative research methods and applying multiple sources of data collection, including a speaking rubric, the teachers' observations, questionnaires, and interviews. The results of the study the effectiveness of IIM not only in enhancing speaking skills but also promoting learners' motivation and satisfaction with this new approach.

\section{Using inverted instruction with EFL pre-service teachers}

EFL pre-service teachers should acquire educational excellence by becoming proficient in communicating in English, which is of utmost importance in their 
profession as teachers (Bishop \& Verleger, 2013). They need to be taught new approaches for improving communication skills, especially the oral ones, for their teaching career (Dove, 2013). Several studies discussed the issue of EFL graduates lacking in the comprehensive qualifying skills seen as essential for EFL teachers, resulting in low employability. Researchers, like Borthwick and Wissler (2003), Crebert et al. (2004), Curry et al. (2003), Kanapathy (2001), Khairi Izwan, and Nurul Lina (2010), Khir (2006), Kim and Park (1997), Lee et al. (2001), (Mohamad, 2017), Pumphrey and Slater (2002), ShaikRiyaz Ahmad (2016), Singh et al. (2013), Suhaily and Faizah (2013), and Vijayaletchumy (2011), have revealed that employers are not satisfied with the graduates' communicative skills. In respect of trying new approaches to improve student teachers' performance, Zakareya and Alahmad (2019) investigated the effect of II on EFL student teachers' teaching performance. Based on the results, the researchers concluded that II was remarkably effective in improving EFL student teacher participants' teaching performance.

In recent years, employers have raised their concern about EFL prospective teachers' oral proficiency, and this contributes to graduate unemployment. Many students at the university level do not acquire oral performance skills, and their perceived self-efficacy is unsatisfactory. The educational system and the instructional approaches used in teaching them might be one of the guilty parties in this issue. Most of the classes in EFL teacher preparation programs are traditional lecture teacher-centered, which impedes students' speaking skills. There is only little communication and a few incidents of interaction between students and teachers in the classroom, if any, which is insufficient to enhance students' English language skills, especially oral communication ones. Graduates' poor oral communication skills affect their ability to secure jobs. They might have the capacity to read and write well, yet they could not utilize oral communication, and they were not proficient enough to initiate a conversation or create a flow of speech. Those graduates are deficient in their communicative abilities, basically, the oral ones, which produce less proficiently equipped communicators.

Due to the quick change and constant development of the job market, EFL teachers are required to develop the necessary qualifications and, most importantly, to acquire "good speaking skills." As Yaman (2014) mentions, speaking skills development is considerably challenging to develop in EFL contexts, like in Egypt, 
due to teachers' transmission-based instruction approach, lack of motivation, students' tendency to speak their native language (NL) in the classrooms and teachers' speaking deficiency. Therefore, there is a need to carry out more studies on using the II model to improve speaking skills, especially for EFL pre-service teachers. Hence, the current research targeted this issue, and in this context, it might provide some insight that could be valuable in implementing IIM for enhancing EFL pre-service teachers' oral performance. There might be a high probability that real opportunities for language practice through IIM would raise the participants' confidence and motivate them to use the English Language effectively. Thus, the purpose of this study was to investigate the effect of using IIM on enhancing the participants' oral performance.

\section{Context of the problem}

It is undeniable that speaking skill is generally neglected in FL classrooms, and it requires much practice to develop, yet teaching it is challenging for language teachers, especially if they are non-native speakers of the TL. In an ESL context, learners have many opportunities to practice the TL outside the classroom, even with its native speakers. However, the EFL context is different as the only chance for the TL to be taught inside the classroom. Egypt is an EFL context where English language learners have less chance to practice their speaking skills in natural communication settings. II is a novel, innovative teaching approach that is rapidly gaining recognition as a useful tool for developing speaking skills of EFL learners. Although English oral skills have often been a somewhat neglected aspect of EFL instruction within the educational context and in EFL teachers' preparation programs, in particular, they nonetheless represent a fundamental language component for any successful EFL teacher in real classroom settings. With a few exceptions, pre-service teachers' exams have always focused on the assessment of the written skills. With the increasing demands for competent EFL teachers and the particular focus from the prospective employers' side concerning the communicative competence in spoken English, II might considerably assist in better preparation and specialization on the part of the teachers.

\section{Statement of the study problem}

Based on what has been aforementioned, the study problem could be stated as follows: There is a research gap investigating the effect of using inverted instruction on enhancing the oral performance of EFL pre-service teachers. The 
targeted components of the EFL pre-service teachers' oral performance are mainly: their fluency and coherence, grammatical range and accuracy, lexical resource, and pronunciation in the TL.

\section{Objectives of the study}

This study was carried out to achieve the following objectives:

1) To investigate the effect of using inverted instruction model on EFL pre-service teachers' oral performance.

2) To identify pre-service teachers' perceptions and their reflections regarding the inverted instruction approach used in the classroom.

The main focus was to find an unconventional way to enhance the oral performance of EFL teacher candidates, which has been generally neglected in their preparation programs, despite its crucial importance in language pedagogy.

\section{Study questions}

The current study is guided by two research questions;

1) Can inverted instruction enhance the oral performance of EFL pre-service teachers?

2) To what extent do EFL pre-service teachers appreciate the inverted instruction model used in the classroom?

\section{Study hypotheses}

1- There is no statistically significant difference in the pre-test scores of EFL preservice teachers in the experimental and control groups before the intervention process of the inverted instruction.

2-There would be a statistically significant difference in the post-test scores of the participants after the intervention process of the inverted instruction.

3-There would be statistically significant differences in post-test scores of the participants concerning the dimensions of oral performance as (a) fluency and coherence, (b) lexical resource, (c) grammatical range and accuracy; and (d) pronunciation?

4-The EFL pre-service teacher participants positively appreciate theinverted instruction model used in the classroom.

\section{Method of the study \\ Design}


The study design is the blueprint for data collection, measurement, and analysis. The researcher utilized a quasi-experimental design with two groups: a control group $(\mathrm{N}=45)$ and an experimental one $(\mathrm{N}=43)$. The experimental group participants received instructional video-lecture format or online learning materials, in addition to reading material with assignments based on course content. In contrast, the control group was taught the same course content in-class using the traditional teaching model, focusing on lectures and explanations by the same teacher/researcher.

\section{Participants}

The participants were 88 EFL pre-service teachers, graduated at the faculty of arts, and enrolled in the general diploma program at Benha Faculty of Education, to be qualified educationally as teachers of English. It was supposed that they had a similar educational background, as they were graduates of the same faculty. Those participants were enrolled in a course entitled "Methods of teaching EFL learners with language problems," taught by the researcher, who is an EFL instruction lecturer.

\section{Procedure}

A pre-test was administered to ascertain the homogeneity of participants and to evaluate their oral performance before the intervention. Each participant had five minutes to perform part2 of the IELTS speaking test as their pre-test that was evaluated by two qualified professional raters. The participants were provided with a range of speaking topics that they selected randomly. The raters recorded the participants' oral performance during the pre-test administration. They used IELTS speaking assessment rubric (Appendix 1) to evaluate the participants speaking performance. The mean scores were calculated for the four dimensions of the speaking assessment rubric; fluency and coherence, lexical resource, grammatical range and accuracy, and pronunciation.

Then, during the intervention process, II was used in teaching the experimental group for eight weeks. During that process, the materials were presented to the experimental group participants on Edmodo, which is an online instructional platform for both teachers and students. Each week, instructional materials were uploaded to the website ahead of time, before class, with enough chance for the students to download and watch them at their convenience. Each participant in the experimental group could interact with his/her classmates and 
with the teacher via Edmodo. While the experimental group learned the course materials through II, the control group had the same course materials in the traditional classroom model.

After the intervention process, the same test was administered to both experimental and control groups by the same raters. The mean scores were calculated for post-test scores to ensure inter-rater reliability; to check the degree of agreement between the two evaluators. The average scores of the two evaluators were calculated and mean scores for overall speaking performance; scores for subdimensions were also calculated.

The inter-rater reliability was calculated using Cronbach's Alpha for both pretest $=0.969$ and post-test $=0.0938$. The mean and standard deviation was calculated for all participants' pre-test and post-test based on the two evaluators' ratings, as shown in Table 1, to establish inter-rater reliability.

Table 1. Means and Standard Deviation of all Participants' Pre-test\& Post-test

\begin{tabular}{|l|c|c|c|}
\hline & Mean & Std. Deviation & N \\
\hline Evaluator (1)Pre-test & .9886 & .82343 & 88 \\
\hline Evaluator (2) Pre-test & .9773 & .80197 & 88 \\
\hline Evaluator (1)Post-test & $\mathbf{2 . 1 0 2 3}$ & 1.14510 & $\mathbf{8 8}$ \\
\hline Evaluator (2) Post-test & $\mathbf{2 . 1 4 7 7}$ & 1.11973 & $\mathbf{8 8}$ \\
\hline
\end{tabular}

It is evident that the rating of the two evaluators is very close to each other, which indicates high inter-rater reliability.

\section{Results and discussion}

Question 1. Can inverted instruction enhance oral performance of EFL pre-service teachers?

\section{Study hypothesis 1:}

There is no statistically significant difference in the oral performance pre-test scores of EFL pre-service teachers in the experimental and control groups before the intervention process of II.

Table 2.Comparison of the control and experimental groups' oral performance pre-test results

\begin{tabular}{|l|l|l|l|l|l|}
\hline & Pre-Test & \multicolumn{1}{|c|}{ Group } & N & Mean Rank & Sum of Ranks \\
\hline Mann-Whitney U & $\mathbf{8 0 5 . 0 0}$ & Cont. group & $\mathbf{4 5}$ & $\mathbf{4 0 . 8 9}$ & $\mathbf{1 8 4 0 . 0 0}$ \\
\hline Wilcoxon W & $\mathbf{1 8 4 0 . 0 0}$ & Exp. group & $\mathbf{4 3}$ & $\mathbf{4 8 . 2 8}$ & $\mathbf{2 0 7 6 . 0 0}$ \\
\hline Z & $\mathbf{1 . 4 0}$ & Total & $\mathbf{8 8}$ & & \\
\hline Asymp. Sig. (2-tailed) & $\mathbf{1 6 1}$ & & & & \\
\hline
\end{tabular}


Table 2 shows that there is no significant difference between the control group and the experimental one in the results of their oral performance pre-test. This means that all participants of the study were of the same level regarding to their oral performance; it is a homogeneous sample.

As for the four dimensions of oral performance: fluency and coherence $(\mathrm{F} \& \mathrm{C})$, lexical resource (LR), grammatical range and accuracy (G\& A), and pronunciation (Pro.) were analyzed to investigate whether there was a significant difference between the control group and the experimental group in any of the four targeted dimensions of oral performance .

Table 3.Comparison between control and experimental groups' oral performance pre-test results regarding the four dimensions

\begin{tabular}{|l|c|c|c|c|c|}
\hline & F\& C & LR & G\& A & Pro. & Total \\
\hline Mann-Whitney U & $\mathbf{7 7 9 . 5 0 0}$ & $\mathbf{9 5 1 . 0 0 0}$ & $\mathbf{7 8 3 . 5 0 0}$ & $\mathbf{8 5 2 . 5 0 0}$ & $\mathbf{8 0 5 . 0 0 0}$ \\
\hline Wilcoxon W & $\mathbf{1 8 1 4 . 5 0 0}$ & $\mathbf{1 9 8 6 . 0 0 0}$ & $\mathbf{1 8 1 8 . 5 0 0}$ & $\mathbf{1 8 8 7 . 5 0 0}$ & $\mathbf{1 8 4 0 . 0 0 0}$ \\
\hline Z & $\mathbf{- 1 . 7 9 8}$ & $\mathbf{- . 1 6 0}$ & $\mathbf{- 1 . 7 4 6}$ & $\mathbf{- 1 . 0 9 6}$ & $\mathbf{- 1 . 4 0 1}$ \\
\hline Asymp. Sig. & .072 & .873 & .081 & .273 & .161 \\
\hline
\end{tabular}

The results shown in table 3 prove that there are no statistically significant differences between experimental and control groups in terms of the four dimensions of oral performance. Pre-test results were set as a covariant variable for post-test analysis and nonparametric tests were used through the rest of the research. The groups' ranks indicate the same results, as shown in table 4.

Table 4. Ranks between Control and Experimental Groups in the Pre-test in regards to the Four Dimensions

\begin{tabular}{|c|c|c|c|c|}
\hline & Group & $\mathbf{N}$ & Mean Rank & Sum of Ranks \\
\hline \multirow[t]{3}{*}{ F\& C } & Cont. group & 45 & 40.32 & 1814.50 \\
\hline & Exp. group & 43 & 48.87 & 2101.50 \\
\hline & Total & 88 & & \\
\hline \multirow[t]{3}{*}{ LR } & Cont. group & 45 & 44.13 & 1986.00 \\
\hline & Exp. group & 43 & 44.88 & 1930.00 \\
\hline & Total & 88 & & \\
\hline \multirow[t]{3}{*}{ G\&A } & Cont. group & 45 & 40.41 & 1818.50 \\
\hline & Exp. group & 43 & 48.78 & 2097.50 \\
\hline & Total & 88 & & \\
\hline \multirow[t]{3}{*}{ Pro. } & Cont. group & 45 & 41.94 & 1887.50 \\
\hline & Exp. group & 43 & 47.17 & 2028.50 \\
\hline & Total & 88 & & \\
\hline \multirow[t]{3}{*}{ Total } & Cont. group & 45 & 40.89 & 1840.00 \\
\hline & Exp. group & 43 & 48.28 & 2076.00 \\
\hline & Total & 88 & & \\
\hline
\end{tabular}


* Note: Oral performance dimension $=\mathrm{Opd}$, fluency and coherence $=\mathrm{F} \& \mathrm{C}$, lexical resource $=\mathrm{LR}$, grammatical range and accuracy $=\mathrm{G} \& \mathrm{~A}$, and pronunciation $=$ Pro.

Study hypothesis 2: There would be a statistically significant difference in the oral performance post-test scores of the participants in the control and experimental groups.

After the eight weeks, intervention process was completed, the same test was administered to both control and experimental groups by the same evaluators. The covariant analysis was administered to analyze the post-test results of both groups. The groups' pre-test scores were set as covariant variables in the analysis.

Table 5. Comparison of the experimental and control groups' oral performance post-test results

\begin{tabular}{|l|c|c|c|c|c|}
\hline & Post-test & Group & N & Mean Rank & Sum of Ranks \\
\hline Mann-Whitney U & $\mathbf{2 1 . 0 0}$ & Cont. group & $\mathbf{4 5}$ & $\mathbf{2 3 . 4 7}$ & $\mathbf{1 0 5 6 . 0 0}$ \\
\hline Wilcoxon W & $\mathbf{1 0 5 6 . 0 0}$ & Exp. group & $\mathbf{4 3}$ & $\mathbf{6 6 . 5 1}$ & $\mathbf{2 8 6 0 . 0 0}$ \\
\hline Z & $\mathbf{- 7 . 9 4 0}$ & Total & $\mathbf{8 8}$ & & \\
\hline Asymp. Sig. (2-tailed) & $\mathbf{. 0 0 0}$ & & & & \\
\hline
\end{tabular}

In table 5, the level of significance is $.000(\mathrm{p}<0.01)$, which verifies the second study hypothesis; that there was a statistically significant difference between the oral performance post-test scores of both groups.

The results affirm that II based model is remarkably effective for enhancing oral performance among EFL pre-service teacher participants.

Study hypothesis 3: There would be statistically significant differences in post-test scores of the students in the control and experimental groups concerning the four dimensions of oral performance; a) fluency and coherence, b) lexical resource, c) grammatical range and accuracy; and d) pronunciation.

To test this hypothesis, data were collected and analyzed through Mann Whitney $\mathrm{U}$ and Wilcoxon $\mathrm{W}$ tests. The findings of each dimension are provided below separately.

A. Post-test scores between the control and experimental groups in terms of 'Fluency and Coherence'

As for the first dimension, fluency and coherence (F\& $\mathrm{C}$ ), control group, and experimental group's post-test scores were statistically analyzed. Table 6 shows the results for $\mathrm{F} \& \mathrm{C}$ in detail. 
Table 6. Comparison between Post-test results of control and experimental groups in terms of 'Fluency and Coherence' (F\& $C)$

\begin{tabular}{|l|c|c|c|c|c|}
\hline & F\& C & Group & N & Mean Rank & Sum of Ranks \\
\hline Mann-Whitney U & $\mathbf{6 5 . 0 0}$ & Cont. group & 45 & $\mathbf{2 4 . 4 4}$ & $\mathbf{1 1 0 0 . 0 0}$ \\
\hline Wilcoxon W & $\mathbf{1 1 0 0 . 0}$ & Exp. group & $\mathbf{4 3}$ & $\mathbf{6 5 . 4 9}$ & $\mathbf{2 8 1 6 . 0 0}$ \\
\hline Z & $-\mathbf{- 7 . 7 9 6}$ & Total & $\mathbf{8 8}$ & & \\
\hline Asymp. Sig. (2-tailed) & $\mathbf{. 0 0 0}$ & & & & \\
\hline
\end{tabular}

Table 6 shows that there is a statistically significant difference between posttest scores for control and experimental groups in 'fluency and coherence.' The level of significance is $0.000(\mathrm{p}<0.01)$, which means that the II based pedagogy is highly effective in enhancing EFL pre-service teacher participants' fluency and coherence in the TL.

B. Post-test scores between the control and experimental groups in terms of 'Lexical Resource'

Concerning the second dimension, lexical resource (LR), control andexperimental group's post-test scores were statistically analyzed. The results of LR for both groups after the intervention process are presented below in detail in Table 7.

Table 7. Comparison between Post-test results of control and experimental groups in terms of 'Lexical Resource' (LR)

\begin{tabular}{|l|c|c|c|c|c|}
\hline & LR & Group & N & Mean Rank & Sum of \\
\hline Mann-Whitney U & 34.00 & Cont. group & 45 & 23.76 & 1069.00 \\
\hline Wilcoxon W & 1069.0 & Exp. group & 43 & 66.21 & 2847.00 \\
\hline Z & -8.300 & Total & 88 & & \\
\hline Asymp. Sig. (2-tailed) & .000 & & & & \\
\hline
\end{tabular}

Table 7 shows that there is a statistically significant difference between the post-test results of the two groups in 'lexical resource.' The level of significance is $0.000(\mathrm{p}<0.01)$, which means that the II model is significantly effective in enhancing EFL pre-service teacher participants' lexical resource and vocabulary knowledge.

C. Post-test scores between the control and experimental groups in terms of 'Grammatical Range and Accuracy'

Regarding the third dimension, which is grammatical range and accuracy (G\& A), post-test results for both groups were statistically analyzed through Mann Whitney $\mathrm{U}$ and Wilcoxon $\mathrm{W}$ tests. Table 8 presents results in detail. 
Table 8. Comparison between Post-test results of control and experimental groups in terms of 'Grammatical Range and Accuracy' (G\& A)

\begin{tabular}{|l|c|c|c|c|c|}
\hline & G\& A & Group & N & Mean Rank & Sum of \\
\hline Mann-Whitney U & 512.00 & Cont. group & 45 & 34.38 & 1547.00 \\
\hline Wilcoxon W & 1547.00 & Exp. group & 43 & 55.09 & 2369.00 \\
\hline Z & -4.864 & Total & 88 & & \\
\hline Asymp. Sig. (2-tailed) & .000 & & & & \\
\hline
\end{tabular}

Table 8 reveals that there is a statistically significant difference between posttest results for control and experimental groups in terms of the 'grammatical range and accuracy' dimension. The level of significance is $.000(\mathrm{p}<0.01)$, which means that II based model is very effective in enhancing EFL pre-service teacher participants' accuracy in speaking the TL as well as their grammar knowledge.

D. Post-test scores between the control and experimental groups in terms of 'Pronunciation.'

The last dimension is pronunciation (Pro.), of which post-test results for both groups were statistically analyzed through Mann Whitney $\mathrm{U}$ and Wilcoxon $\mathrm{W}$ tests. Table 9 presents the results in detail.

Table 9. Comparison between Post-test results of control and experimental groups in terms of 'Pronunciation' (Pro.)

\begin{tabular}{|l|c|c|c|c|c|}
\hline & Pro. & Group & N & Mean Rank & Sum of \\
\hline Mann-Whitney U & $\mathbf{1 3 7 . 5 0}$ & Cont. group & 45 & $\mathbf{2 6 . 0 6}$ & $\mathbf{1 1 7 2 . 5 0}$ \\
\hline Wilcoxon W & $\mathbf{1 1 7 2 . 5 0}$ & Exp. group & $\mathbf{4 3}$ & $\mathbf{6 3 . 8 0}$ & $\mathbf{2 7 4 3 . 5 0}$ \\
\hline Z & -7.119 & Total & $\mathbf{8 8}$ & & \\
\hline Asymp. Sig. (2-tailed) & $\mathbf{. 0 0 0}$ & & & & \\
\hline
\end{tabular}

Table 9 shows that there is a statistically significant difference between posttest results between the control and experimental groups in terms of the 'pronunciation' dimension. The level of significance is $.000(\mathrm{p}<0.01)$, which means that II based pedagogy is very effective in enhancing EFL pre-service teacher participants' pronunciation in the TL.

Based on the quantitative data analysis and debriefing the results, in Table 10, hypothesis 3 is affirmed, and EFL pre-service teacher participants showed a higher level of oral performance after the intervention process, as they improved significantly in all four dimensions. 
Table 10. Ranks between the Control and Experimental Groups in the oral performance Pre and post-test results

\begin{tabular}{|c|c|c|c|c|}
\hline $\begin{array}{l}\text { Oral } \\
\text { performance }\end{array}$ & Group & $\mathbf{N}$ & Mean Rank & Sum of Ranks \\
\hline \multirow[t]{3}{*}{ F\& C (Pre) } & Cont. group & 45 & 40.32 & 1814.50 \\
\hline & Exp. group & 43 & 48.87 & 2101.50 \\
\hline & Total & 88 & & \\
\hline \multirow[t]{3}{*}{ F\& C (Post) } & Cont. group & 45 & 24.44 & 1100.00 \\
\hline & Exp. group & 43 & 65.49 & 2816.00 \\
\hline & Total & 88 & & \\
\hline \multirow[t]{3}{*}{ LR (Pre) } & Cont. group & 45 & 44.13 & 1986.00 \\
\hline & \begin{tabular}{|l|} 
Exp. group \\
\end{tabular} & 43 & 44.88 & 1930.00 \\
\hline & Total & 88 & & \\
\hline \multirow[t]{3}{*}{ LR (Post) } & Cont. group & 45 & 23.76 & 1069.00 \\
\hline & Exp. group & 43 & 66.21 & 2847.00 \\
\hline & Total & 88 & & \\
\hline $\begin{array}{l}\text { Oral } \\
\text { performance }\end{array}$ & Group & $\mathbf{N}$ & Mean Rank & Sum of Ranks \\
\hline \multirow[t]{3}{*}{ G\& A (pre) } & Cont. group & 45 & 40.41 & 1818.50 \\
\hline & Exp. group & 43 & 48.78 & 2097.50 \\
\hline & Total & 88 & & \\
\hline \multirow[t]{3}{*}{ G\& A (Post) } & Cont. group & 45 & 34.38 & 1547.00 \\
\hline & Exp. group & 43 & 55.09 & 2369.00 \\
\hline & Total & 88 & & \\
\hline \multirow[t]{3}{*}{ Pro. (Pre) } & Cont. group & 45 & 41.94 & 1887.50 \\
\hline & Exp. group & 43 & 47.17 & 2028.50 \\
\hline & Total & 88 & & \\
\hline \multirow[t]{3}{*}{ Pro. (Post) } & Cont. group & 45 & 26.06 & 1172.50 \\
\hline & Exp. group & 43 & 63.80 & 2743.50 \\
\hline & Total & 88 & & \\
\hline \multirow[t]{3}{*}{ Total (Pre) } & Cont. group & 45 & 40.89 & 1840.00 \\
\hline & Exp. group & 43 & 48.28 & 2076.00 \\
\hline & Total & 88 & & \\
\hline \multirow[t]{3}{*}{ Total (Post) } & Cont. group & 45 & 23.47 & 1056.00 \\
\hline & Exp. group & 43 & 66.51 & 2860.00 \\
\hline & Total & 88 & & \\
\hline
\end{tabular}

It is shown in Table 10 in detail that the participants of the experimental group have significant development in their fluency, accuracy, grammar range, lexical resource, and pronunciation. The findings manifest that there are statistically 
significant differences between the control group and the experimental group's post-test results. While the experimental group has a 66.51 mean rank, the control group has 23.47 mean in post-test results. The results indicate that the intervention process is remarkably effective in enhancing the experimental group participants' oral performance.

Table 11, which includes all four oral performance dimensions, shows that the participants of the experimental group have experienced a significant improvement.

Table 11: Comparison between Pred Post tests results in the oral performance dimensions of the control and the experimental groups

\begin{tabular}{|c|c|c|c|c|c|c|c|c|c|c|}
\hline & $\begin{array}{l}\text { F\& C } \\
\text { (Pre) }\end{array}$ & \begin{tabular}{|l} 
F\& C \\
(Post)
\end{tabular} & $\begin{array}{c}\text { LR } \\
\text { (Pre) }\end{array}$ & \begin{tabular}{|c|} 
LR \\
(Post) \\
\end{tabular} & $\begin{array}{l}\text { G\& A } \\
\text { (Pre) }\end{array}$ & $\begin{array}{l}\text { G\& A } \\
\text { (Post }\end{array}$ & $\begin{array}{l}\text { Pro. } \\
\text { (Pre) }\end{array}$ & \begin{tabular}{|l} 
Pro. \\
(Post)
\end{tabular} & $\begin{array}{l}\text { Total } \\
\text { (Pre) }\end{array}$ & \begin{tabular}{|l|} 
Total \\
(Post)
\end{tabular} \\
\hline \begin{tabular}{|l|} 
Mann- \\
Whitney U \\
\end{tabular} & $\begin{array}{l}779.5 \\
0\end{array}$ & 65.00 & 951.00 & 34.00 & 783.50 & 512.00 & 852.500 & 137.50 & 805.00 & 21.00 \\
\hline $\begin{array}{l}\text { Wilcoxon } \\
\text { W }\end{array}$ & $\begin{array}{l}1814 . \\
50\end{array}$ & $\begin{array}{l}1100 . \\
00\end{array}$ & 1986.0 & 1069.0 & $\begin{array}{l}1818.5 \\
0\end{array}$ & $\begin{array}{l}1547.0 \\
0\end{array}$ & $\begin{array}{l}1887.50 \\
0\end{array}$ & $\begin{array}{l}1172.5 \\
0^{1}\end{array}$ & $\begin{array}{l}1840.0 \\
0\end{array}$ & $\begin{array}{l}1056.0 \\
0\end{array}$ \\
\hline $\mathbf{Z}$ & -1.798 & -7.796 & -.160 & -8.300 & -1.746 & -4.864 & -1.096 & -7.119 & -1.401 & -7.940 \\
\hline \begin{tabular}{|l} 
Asymp. Sig. \\
(2-tailed)
\end{tabular} & .072 & .000 & .873 & .000 & .081 & .000 & .273 & .000 & .161 & .000 \\
\hline
\end{tabular}

The results for $\mathrm{F} \& \mathrm{C}$ verified that participants of the experimental group experienced significantly developed in their fluency, and that can be interpreted as II provided a natural environment and relaxed atmosphere for language enhancement. While the experimental group had 65.49, the control group had 24.44 in F\& $\mathrm{C}$ in the post-test. It shows that the experimental group achieved improvement in fluency and coherence. This finding could be interpreted because II provided more time for practice; experimental group participants had an excellent chance to practice their speaking skills in class times. Besides, they had the chance to adjust their own learning pace (Bergman \& Sams, 2012), as they could watch the videos as much as they want. Hence, they could learn better and achieve the target goals more efficiently than the control group with the traditional lecture. In contrast to traditional lecture-based instruction, II increased the time for practice in the classroom. Besides, class times are spent with peers and the teacher communicating and establishing rapport through individual learning, pair work, group work, and other activities.

The results of LR were also similar to the ones with F\& C. There were statistically significant differences between the two groups concerning lexical 
knowledge development, and their mean rank was 66.21 for the experimental group and 23.76 for the control one in LR, which is 'lexical resource.' In the intervention process, the learning activities were supported with reading materials in which participants were employing their reading skills, such as skimming and scanning. Each week, at least two reading articles were uploaded to Edmodo before the class session. Those articles generally presented the theme of the week and are related to the theoretical information and content knowledge of the course. It aimed to develop students' understanding of the content and to create background information for classroom discussions and activities. The experimental group participants covered the reading materials before class sessions, whereas. The control group had to deal with it during class time. The interpretation of this finding could be backed up with the consideration that the participants were exposed to considerable listening through the videos and many reading activities with reading assignments before the lesson. Even though the primary purpose of these activities was to create background information necessary to understand the course content, the participants still experienced considerable development in their lexical scope.

When the results of G\& A were examined, it was evident that similar results as F\& $\mathrm{C}$ and LR were attained. While the control group had 34.38, the experimental one had 55.09 in post-test results for $G \& A$. The results indicated that the experimental group had improved in their grammatical knowledge and accuracy. A suggested interpretation for this might be because the experimental group had the learning materials before the class sessions, they had more chance to study these materials at their own pace, which allowed them to develop their grammatical knowledge more and to promote their accuracy.

Pronunciation (Pro.) as the fourth dimension, had almost similar results like the other three dimensions; the experimental group scored 63.80, meantime the control one had 26.06 in post-test results. A valid interpretation for this finding was that the experimental group participants had the chance to listen to native speakers of the TL while watching the assigned videos, which might have an undeniable effect on improving their pronunciation. Besides, the instructor was always trying to correct their pronunciation mistakes and fix them persistently during class sessions as well.

Reviewing the results, it was apparent that fluency and pronunciation were the most developed dimensions, which were the main components of oral performance 
that in the current experimental intervention was aiming to enhance. The findings show that experimental group participants took advantage of the videos to develop their pronunciation skills, and II provided the chance for adjusting the learning pace for each one of them. Thus, it could be interpreted that they watched the videos repeatedly to correct their pronunciation. However, the control group had lower scores in the pronunciation dimension because they learned the same course content in traditional lecture format. The results indicate that the II model was highly effective in enhancing pronunciation skills among EFL pre-service teacher participants.

The significant difference could be attributed to the change of the instructional approach, which was the intervention process using the II model. As both groups had the same course content, materials of the course, and the same teacher as well, the control group was taught using the traditional teacher-fronted instruction and lecture-based learning, following the transmittal theory of teaching. Meanwhile, the experimental group was taught through the II model during the intervention process. The results indicate that the intervention process is remarkably effective in enhancing EFL pre-service teachers' oral performance. As was mentioned in the review of literature, the II could be based theoretically on constructivism, which adopted the student-centered learning theory and learner autonomy. This theory shared a clear viewpoint that learning could be more constructive when learners are active participants, through a relaxing, non-threatening environment, and the teacher is a facilitator or a guide on the side.

With the II, participants and the teacher had more time to communicate during class sessions. As the course content was delivered through the II model, in-class times were spent for practice through different instructional activities, where the learning environment was created for both the participants and teacher to interact. The researcher used several kinds of oral activities during the class sessions as a follow up after each video segment or reading assignment. Among those activities were: role-playing, interviewing someone, sharing reactions and opinions, debating different sides of an issue, providing a summary, paraphrasing selected parts of the video, providing a 'critical review' of the segment or the assigned material, carrying out a group survey based on the topic. A speaking rubric (Appendix 2), based on the videos watched, was used for fluency activities.

Before beginning each activity, the researcher made sure that participants understand the task in hand and how to perform it. She used to adjust the tasks to 
the participants' interests and abilities. Each activity had time limits, and as the participants began, she made sure to provide language guidance and support as needed. After practicing the activity in pairs or small groups, the researcher allowed each group to try the activity in front of the whole class. There were drastic changes in the participants' oral performance, from the beginning of the course through the end of it. The researcher was using the speaking rubric for fluency activities to track those changes along with the experiment. Some participants at the beginning used to refuse to participate, and some of them even cried when asked to speak because they felt reluctant to take part in those kinds of activities. They were not used to communicate orally with the teacher or with their peers using the TL, and they were embarrassed to use the TL in front of the whole class, as they lacked the required confidence to do that and they also suffered from apparent symptoms of communication apprehension, especially with oral communication.

The researcher used scaffolding as an integral part of II as it was an essential aspect of constructivism and cooperative learning. The participants asked questions to the teacher during the class sessions, if they did not understand some points in the videos or reading materials, and the teacher used to clarify these points through discussions and scaffold the participants' learning. In the II sessions, class sessions had practice part in which the participants work in pairs or groups as peer communication. It might be seen as an extra outcome of II as it enhanced social learning and oral communication among the participants.

During the intervention process, most of the class sessions were spent doing collaborative tasks and productive activities. The course was adapted and designed to turn the participants into more interactive learners during class sessions. Various speaking activities were designed and modified to be integrated into the course content, to encourage participants to speak spontaneously and freely.

Question 2. To what extent do EFL pre-service teachers appreciate the inverted instruction model used in the classroom?

Study hypothesis 4. The EFL pre-service teacher participants positively appreciate the inverted instruction model used in the classroom.

To support the quantitative data collected, the researcher designed a survey on surveymonkey.com and invited the participants to respond to it. The following was qualitative data collected and interpreted using the participants' comments on the survey, in addition to reflective essays that the researcher prompted for them. 
Table 12. Participants' perceptions/reflections of the Inverted Instruction approach

\begin{tabular}{|c|c|c|c|c|c|c|c|}
\hline & Statements & $\mathbf{S A}$ & $\mathbf{A}$ & $\mathbf{N}$ & $\mathbf{D}$ & SD & Total \\
\hline \multirow[t]{2}{*}{$\mathbf{1}$} & \multirow{2}{*}{$\begin{array}{l}\text { During the inverted class, I } \\
\text { had more opportunities to } \\
\text { speak English, which made } \\
\text { me more fluent. }\end{array}$} & 15 & 28 & $\mathbf{0}$ & $\mathbf{0}$ & $\mathbf{0}$ & 43 \\
\hline & & $34.9 \%$ & $65.1 \%$ & $0 \%$ & $0 \%$ & $0 \%$ & $100 \%$ \\
\hline \multirow[t]{2}{*}{2} & \multirow{2}{*}{$\begin{array}{l}\text { Video lectures in English } \\
\text { were fascinating to watch } \\
\text { and it had helped me } \\
\text { improve my pronunciation. }\end{array}$} & 9 & 30 & 3 & 1 & $\mathbf{0}$ & 43 \\
\hline & & $20.9 \%$ & $69.8 \%$ & $7 \%$ & $2.3 \%$ & $0 \%$ & $100 \%$ \\
\hline \multirow[t]{2}{*}{3} & \multirow{2}{*}{$\begin{array}{l}\text { After watching the video, I } \\
\text { could have a better } \\
\text { understanding of the topic. }\end{array}$} & 17 & 18 & 7 & 1 & $\mathbf{0}$ & 43 \\
\hline & & $39.5 \%$ & $41.9 \%$ & $16.3 \%$ & $2.3 \%$ & $0 \%$ & $100 \%$ \\
\hline \multirow[t]{2}{*}{4} & \multirow{2}{*}{$\begin{array}{l}\text { Reading the assigned } \\
\text { materials before class } \\
\text { helped to improve my } \\
\text { reading skills and enriched } \\
\text { my vocabulary as well. }\end{array}$} & 15 & 23 & 3 & 2 & $\mathbf{0}$ & 43 \\
\hline & & $34.9 \%$ & $53.5 \%$ & $7 \%$ & $4.6 \%$ & $0 \%$ & $100 \%$ \\
\hline \multirow[t]{2}{*}{5} & \multirow{2}{*}{$\begin{array}{l}\text { I became confident after } \\
\text { knowing the main ideas of } \\
\text { the topic before coming to } \\
\text { class. }\end{array}$} & 14 & 20 & 7 & 2 & 0 & 43 \\
\hline & & $32.6 \%$ & $46.5 \%$ & $16.3 \%$ & $4.6 \%$ & & $100 \%$ \\
\hline & Statements & SA & $\mathbf{A}$ & $\mathbf{N}$ & D & SD & Total \\
\hline \multirow[t]{2}{*}{6} & \multirow{2}{*}{$\begin{array}{l}\text { I developed my speaking } \\
\text { skills through watching the } \\
\text { videos and also through } \\
\text { class discussions with my } \\
\text { peers and with the teacher. }\end{array}$} & 17 & 22 & 4 & $\mathbf{0}$ & $\mathbf{0}$ & 43 \\
\hline & & $39.5 \%$ & $51.2 \%$ & $9.3 \%$ & $0 \%$ & $0 \%$ & $100 \%$ \\
\hline \multirow[t]{3}{*}{7} & \multirow{2}{*}{$\begin{array}{l}\text { The interactive activities } \\
\text { used in the inverted class } \\
\text { helped me develop more } \\
\text { fluency and self-confidence. }\end{array}$} & 28 & 13 & 2 & $\mathbf{0}$ & $\mathbf{0}$ & 43 \\
\hline & & $65.1 \%$ & $30.2 \%$ & $4.6 \%$ & $0 \%$ & $0 \%$ & $100 \%$ \\
\hline & Statements & $\mathbf{S A}$ & $\mathbf{A}$ & $\mathbf{N}$ & D & SD & Total \\
\hline \multirow[t]{2}{*}{8} & \multirow{2}{*}{$\begin{array}{l}\text { In the new instructional } \\
\text { model, the teacher had } \\
\text { more time to interact with } \\
\text { each one of us individually. }\end{array}$} & 18 & 17 & 4 & 4 & 0 & 43 \\
\hline & & $41.9 \%$ & $39.5 \%$ & $9.3 \%$ & $9.3 \%$ & $0 \%$ & $100 \%$ \\
\hline \multirow[t]{2}{*}{9} & \multirow{2}{*}{$\begin{array}{l}\text { Although the workload was } \\
\text { heavy, and I had too much } \\
\text { to prepare before class, I } \\
\text { liked this new approach. }\end{array}$} & 10 & 20 & 9 & 4 & 0 & 43 \\
\hline & & $23.3 \%$ & $46.5 \%$ & $20.9 \%$ & $9.3 \%$ & $0 \%$ & $100 \%$ \\
\hline \multirow[t]{2}{*}{10} & \multirow{2}{*}{$\begin{array}{l}\text { The inverted classroom was } \\
\text { more interesting than the } \\
\text { traditional one }\end{array}$} & 23 & 19 & 1 & $\mathbf{0}$ & $\mathbf{0}$ & 43 \\
\hline & & $53.5 \%$ & $44.2 \%$ & $2.3 \%$ & $0 \%$ & $0 \%$ & $100 \%$ \\
\hline
\end{tabular}


Table 12 shows that all the experimental group participants (100\%) strongly agreed that with II, they had more chances to practice and brush their speaking skills, which enhanced their fluency. Accordingly, the II model could be a useful tool to energize the traditional model, as it would motivate both the teacher and learners to promote communicative competence and improve language teaching, which would make language learning objectives more achievable. Then, more than $90 \%$ of the participants showed their enjoyment of video watching and were enthusiastic about its positive effects, as they found it very helpful in improving their pronunciation; only three participants $(7 \%)$ presented a neutral position, and one disagreed $(2.3 \%)$. Regarding understanding the assigned topic, most of the students $(81 \%)$ agreed they had a better understanding of the topic after watching the assigned videos, while there were few neutral and disagreed opinions. This finding revealed that the participants were actively involved in the learning process through the II model, but the teacher could realize some participants might not get access to the internet or figure out the main ideas of the videos due to their language deficiency.

Next, a high percentage of participants (88.4\%) responded positively about improving reading skills and enriching vocabulary via II. They acknowledged that the weekly reading fostered their active learning and promoted their creative and critical thinking skills and other generic skills that they could use inside and outside the classroom. These findings were consistent with the studies done by Basal (2015), Hung (2015), and Stone (2012), which got positive results of selfregulated learning using II. Additionally, the participants confirmed that II enlarged their vocabulary and assisted in dealing with some grammatical issues through reading the assigned materials. II inspired them to become more active in choosing their learning styles and more participative in the language acquisition process, as they had control over their knowledge building.

As for self-esteem, 79.1\% of participants supported the idea of being confident because of their knowledge of the main idea before coming to class. Classroom activities stimulated their intellectual growth because they had more time for critical thinking tasks, as they had already covered the content knowledge in advance. The rest of the respondents (16.3\%) expressed their neutral opinions because they could not understand the videos thoroughly and found it challenging 
to get the targeted ideas, and only two participants disagreed. Some respondents reported that they needed the teacher's explanation after watching the videos or reading the materials.

In terms of speaking skills, most of the students (90.7\%) much valued the videos and classroom discussions because it helped to improve their speaking skills. Learning the language in an EFL context, they had few opportunities to communicate with foreigners in real-life situations. When watching the videos, they had a much better opportunity to listen to native speakers on the screen, and they had the chance to rewind it and re-watch them as many times as they want. Classroom discussions were another source of stimulation to develop both speaking and listening skills spontaneously.

It was very inspiring to realize that $95.3 \%$ of the participants agreed upon an increase of teacher-student as well as student-student interaction with II. Unlike the traditional model, the teacher had more time and opportunities for differentiated instructions and individual interaction. She used to go around the class to listen to the group discussions and participate in their task and elicit some prompts or arguments and answer participants' questions. The participants expressed their positive feelings and appreciation of the individualized care offered to them by the teacher, as she was paying attention to learners' needs when she talked to them friendly in person. The participants asserted that they were empowered to grow intellectually and develop their language skills under the guidance of 'a considerate and loving teacher,' using some of their exact words, according to their description. Meanwhile, $81.4 \%$ of the participants agreed that the II model gave the teacher a chance for individualized instruction and personal interaction with the students. Only four students $(9.3 \%)$ were neutral, and another four disagreed.

To measure students' overall evaluation of II, their opinion of this new approach of instruction, despite the massive workload of class tasks were checked. The results showed that $69.8 \%$ of the participants approved the new approach and expressed liking it; nine (20.9\%) responded neutrally, and four students $(9.3 \%)$ had negative opinions. These findings show that some participants had difficulties coping with the new instructional model. Some of them might prefer the traditional model as they were used to it, where they did not have to complete assignments 
before class and after, or participate in interactive activities or communicate with teacher and peers using the TL.

However, when responding to the last statement about II class as being more engaging than traditional one, $53.5 \%$ of the respondents strongly agreed, $44.2 \%$ agreed, and $2.3 \%$ presented a neutral position. In general, the participants expressed their preference for this technology injected model as they had better knowledge of the content, and concurrently developed EFL language skills, especially speaking.

To conclude, analyzing reflective essays of participants confirmed the results of the quantitative data and went along with the responses of the survey. Most of the participants' ideas and opinions went around the following examples:

- The class was interactive, and it was useful/beneficial for me ...

- I was able to participate in that interactive class ...

- Preparing for the class on my own was good for developing many of my language skills and learning styles ...

- I had enough time to prepare for the class...

- Online materials were resourceful and helped preparing for the class...

- I prefer the hybrid of online learning with the interactive class to the traditional lecture model.

- Some colleagues were not cooperative ...

- During group work, some people wanted to control the whole activity, and some others opted out of participation.

The research findings revealed that instruction tools by using video, online materials, and interactive activities created a positive, relaxed atmosphere among the participants. The collaborative tasks given by the instructor in the class built self-confidence and promoted the ability to engage with peers. The findings also demonstrated that the II model was a positive experience for EFL pre-service teachers because it improved their speaking skills and enhanced their oral performance.

\section{Conclusions}

Various conclusions could be drawn from the findings of the study. To start with, utilizing II in enhancing the oral performance of EFL learners was a fruitful and worthwhile approach. Another conclusion that could be extracted from the 
study's findings was that a constructivist perspective, where independent and collaborative learning had a remarkable role, could be successfully utilized in developing EFL instruction. As II provided chances for EFL pre-service teachers to be autonomous learners, to study course content before the lesson, each one learned it independently, at their own pace, and their most convenience. Class time was devoted to interaction with peers and teacher through engaging in collaborative speaking activities, where each student had the chance to communicate orally in various situations. Based on constructivism perspectives, this experimental study emphasized student-centered active learning and functional collaboration.

In II, experimental group participants were responsible for their learning of content knowledge in advance before class, so that they were active participants in the learning process. During class sessions, a relaxed student-centered atmosphere was created to enhance the target oral performance with the help of the collaborative pedagogical tasks and creative speaking activities. Besides, II fostered learners' autonomy, as the participants adjusted their own learning pace. Additionally, the flexible learning environment that was provided through II stimulated the participants' enthusiasm and promoted their learning objectives. Finally, it was apparent that the participants had positive attitudes towards II even though it was entirely new for them.

\section{Suggestions for further studies}

- More comprehensible studies could be carried out with different groups of participants, like undergraduate students, in-service training programs, with a longer intervention process.

- Teachers' awareness of II implementation and their readiness to utilize it, emerging challenges they face, barriers, and obstacles they have to overcome, and the constructivist perspective of II should be investigated.

- The study of autonomous learners is suggested and reinforcing the idea which might encourage and contribute to learners' educational development and success.

- The study of innovation potential instructional models is strongly reinforced and strengthening the positions of modern pedagogical technologies in the higher educational institutes. 


\section{Appendix (1)}

Assessing Speaking Performance IELTS

IELTS Speaking Band Descriptors (public version)

\begin{tabular}{|c|c|c|c|c|}
\hline Band & Fluency and & $\begin{array}{c}\text { Lexical } \\
\text { resource }\end{array}$ & $\begin{array}{c}\text { Grammatical } \\
\text { range }\end{array}$ & Pronunciation \\
\hline & coherence & & and accuracy & \\
\hline \multirow[t]{10}{*}{9} & $\begin{array}{l}\text { - speaks fluently } \\
\text { with only rare }\end{array}$ & $\begin{array}{c}\bullet \text { uses } \\
\text { vocabulary } \\
\text { with full }\end{array}$ & $\begin{array}{l}\text { - uses a full range } \\
\text { of }\end{array}$ & $\begin{array}{l}- \text { uses a full range } \\
\text { of }\end{array}$ \\
\hline & $\begin{array}{l}\text { repetition or self- } \\
\text { correction; }\end{array}$ & $\begin{array}{c}\text { flexibility and } \\
\text { precision in }\end{array}$ & $\begin{array}{c}\text { structures } \\
\text { naturally and }\end{array}$ & $\begin{array}{l}\text { pronunciation } \\
\text { features with }\end{array}$ \\
\hline & $\begin{array}{c}\text { any hesitation is } \\
\text { content- }\end{array}$ & all topics & appropriately & $\begin{array}{c}\text { precision and } \\
\text { subtlety }\end{array}$ \\
\hline & related rather & $\begin{array}{c}\text { uses idiomatic } \\
\text { language }\end{array}$ & $\begin{array}{l}\bullet \text { produces } \\
\text { consistently }\end{array}$ & $\begin{array}{c}\text { - sustains flexible } \\
\text { use of }\end{array}$ \\
\hline & $\begin{array}{l}\text { than to find } \\
\text { words or } \\
\text { grammar } \\
\end{array}$ & $\begin{array}{c}\text { naturally and } \\
\text { accurately }\end{array}$ & $\begin{array}{c}\text { accurate } \\
\text { structures apart }\end{array}$ & $\begin{array}{c}\text { features } \\
\text { throughout }\end{array}$ \\
\hline & $\begin{array}{l}\text { • speaks } \\
\text { coherently with } \\
\text { fully }\end{array}$ & & $\begin{array}{c}\text { from 'slips' } \\
\text { characteristic of }\end{array}$ & $\begin{array}{c}\text { - is effortless to } \\
\text { understand }\end{array}$ \\
\hline & $\begin{array}{l}\text { appropriate } \\
\text { cohesive }\end{array}$ & & $\begin{array}{l}\text { native speaker } \\
\text { speech }\end{array}$ & \\
\hline & features & & & \\
\hline & $\begin{array}{l}\text { develops topics } \\
\text { fully and }\end{array}$ & & & \\
\hline & Appropriately & & & \\
\hline \multirow[t]{9}{*}{8} & $\begin{array}{c}\text { speaks fluently } \\
\text { with only }\end{array}$ & $\begin{array}{l}\text { - uses a wide } \\
\text { vocabulary }\end{array}$ & $\begin{array}{l}\text { - uses a wide } \\
\text { range of }\end{array}$ & $\begin{array}{c}\cdot \text { uses a wide } \\
\text { range of }\end{array}$ \\
\hline & $\begin{array}{c}\text { occasional } \\
\text { repetition or }\end{array}$ & $\begin{array}{c}\text { resource } \\
\text { readily and }\end{array}$ & $\begin{array}{l}\text { structures } \\
\text { flexibly }\end{array}$ & $\begin{array}{c}\text { pronunciation } \\
\text { features }\end{array}$ \\
\hline & $\begin{array}{c}\text { self-correction; } \\
\text { hesitation is }\end{array}$ & $\begin{array}{c}\text { flexibly to } \\
\text { convey precise }\end{array}$ & $\begin{array}{c}\text { • produces a } \\
\text { majority of error- }\end{array}$ & $\begin{array}{c}\text { - sustains flexible } \\
\text { use of }\end{array}$ \\
\hline & $\begin{array}{c}\text { usually content- } \\
\text { related }\end{array}$ & meaning & $\begin{array}{l}\text { free sentences } \\
\text { with }\end{array}$ & features, with only \\
\hline & $\begin{array}{c}\text { and only rarely to } \\
\text { search for }\end{array}$ & $\begin{array}{l}\bullet \text { uses less } \\
\text { common and }\end{array}$ & $\begin{array}{l}\text { only very } \\
\text { occasional }\end{array}$ & occasional lapses \\
\hline & language & $\begin{array}{c}\text { idiomatic } \\
\text { vocabulary }\end{array}$ & $\begin{array}{c}\text { inappropriacies } \\
\text { or basic/non- }\end{array}$ & $\begin{array}{l}\bullet \text { is easy to } \\
\text { understand }\end{array}$ \\
\hline & $\begin{array}{c}\text { develops topics } \\
\text { coherently }\end{array}$ & $\begin{array}{c}\text { skillfully, with } \\
\text { occasional }\end{array}$ & systematic & $\begin{array}{c}\text { throughout; L1 } \\
\text { accent has }\end{array}$ \\
\hline & and appropriately & inaccuracies & errors & minimal effect on \\
\hline & & $\begin{array}{c}\cdot \text { uses } \\
\text { paraphrase }\end{array}$ & & intelligibility \\
\hline
\end{tabular}




\begin{tabular}{|c|c|c|c|c|}
\hline & & effectively & & \\
\hline & & as required & & \\
\hline \multirow[t]{10}{*}{7} & $\begin{array}{c}\text { - speaks at length } \\
\text { without }\end{array}$ & $\begin{array}{c}\bullet \text { uses } \\
\text { vocabulary } \\
\text { resource }\end{array}$ & $\begin{array}{l}\text { - uses a range of } \\
\text { complex }\end{array}$ & $\begin{array}{c}\text { - shows all the } \\
\text { positive }\end{array}$ \\
\hline & $\begin{array}{c}\text { noticeable effort } \\
\text { or loss of }\end{array}$ & $\begin{array}{c}\text { flexibly to } \\
\text { discuss a }\end{array}$ & $\begin{array}{c}\begin{array}{c}\text { structures with } \\
\text { some }\end{array} \\
\end{array}$ & $\begin{array}{c}\text { features of Band } 6 \\
\text { and } \\
\end{array}$ \\
\hline & coherence & $\begin{array}{c}\text { variety of } \\
\text { topics }\end{array}$ & flexibility & $\begin{array}{c}\text { some, but not all, } \\
\text { of the }\end{array}$ \\
\hline & $\begin{array}{c}\bullet \text { may } \\
\text { demonstrate } \\
\text { language- }\end{array}$ & $\begin{array}{c}\text { - uses some less } \\
\text { common and }\end{array}$ & $\begin{array}{l}\bullet \text { frequently } \\
\text { produces error- }\end{array}$ & $\begin{array}{c}\text { positive features } \\
\text { of Band } 8\end{array}$ \\
\hline & $\begin{array}{c}\text { related hesitation } \\
\text { at }\end{array}$ & $\begin{array}{c}\text { idiomatic } \\
\text { vocabulary }\end{array}$ & $\begin{array}{c}\text { free sentences, } \\
\text { though }\end{array}$ & \\
\hline & $\begin{array}{c}\text { times, or some } \\
\text { repetition }\end{array}$ & $\begin{array}{c}\text { and shows } \\
\text { some } \\
\text { awareness }\end{array}$ & $\begin{array}{c}\text { some } \\
\text { grammatical } \\
\text { mistakes }\end{array}$ & \\
\hline & $\begin{array}{l}\text { and/or self- } \\
\text { correction }\end{array}$ & of style and & persist & \\
\hline & $\begin{array}{c}\text { - uses a range of } \\
\text { connectives }\end{array}$ & $\begin{array}{c}\text { collocation, } \\
\text { with some }\end{array}$ & & \\
\hline & and discourse & \begin{tabular}{c|} 
inappropriate \\
choices
\end{tabular} & & \\
\hline & $\begin{array}{c}\text { markers with } \\
\text { some flexibility }\end{array}$ & $\begin{array}{c}\bullet \text { uses } \\
\text { paraphrase } \\
\text { effectively }\end{array}$ & & \\
\hline Band & $\begin{array}{l}\text { Fluency and } \\
\text { coherence }\end{array}$ & Lexical range & $\begin{array}{c}\text { Grammatical } \\
\text { range and } \\
\text { accuracy }\end{array}$ & Pronunciation \\
\hline \multirow[t]{8}{*}{6} & $\begin{array}{l}\bullet \text { is willing to } \\
\text { speak at length, }\end{array}$ & $\begin{array}{c}\text { - has a wide } \\
\text { enough }\end{array}$ & $\begin{array}{l}- \text { uses a mix of } \\
\text { simple and }\end{array}$ & $\cdot$ uses a range of \\
\hline & though may lose & $\begin{array}{c}\text { vocabulary to } \\
\text { discuss topics } \\
\text { at }\end{array}$ & $\begin{array}{c}\text { complex } \\
\text { structures, but }\end{array}$ & $\begin{array}{l}\text { pronunciation } \\
\text { features with }\end{array}$ \\
\hline & $\begin{array}{l}\text { coherence at } \\
\text { times due to }\end{array}$ & $\begin{array}{c}\text { length and } \\
\text { make meaning }\end{array}$ & $\begin{array}{c}\text { with limited } \\
\text { flexibility }\end{array}$ & mixed \\
\hline & $\begin{array}{l}\text { occasional } \\
\text { repetition, }\end{array}$ & clear in spite of & $\begin{array}{c}\bullet \text { may make } \\
\text { frequent mistakes }\end{array}$ & control \\
\hline & $\begin{array}{c}\text { self-correction or } \\
\text { hesitation }\end{array}$ & inappropriacies & with complex & $\begin{array}{l}\text { - shows some } \\
\text { effective use }\end{array}$ \\
\hline & $\begin{array}{c}\text { - uses a range of } \\
\text { connectives }\end{array}$ & $\begin{array}{l}\text { - generally } \\
\text { paraphrases }\end{array}$ & $\begin{array}{c}\text { structures, } \\
\text { though these } \\
\text { rarely }\end{array}$ & $\begin{array}{c}\text { of features but } \\
\text { this is }\end{array}$ \\
\hline & and discourse & successfully & cause & not sustained \\
\hline & $\begin{array}{c}\text { markers but not } \\
\text { always }\end{array}$ & & $\begin{array}{c}\text { comprehension } \\
\text { problems }\end{array}$ & - can generally be \\
\hline
\end{tabular}




\begin{tabular}{|c|c|c|c|c|}
\hline & appropriately & & & $\begin{array}{l}\text { understood } \\
\text { throughout, }\end{array}$ \\
\hline & & & & though \\
\hline & & & & $\begin{array}{c}\text { mispronunciation } \\
\text { of }\end{array}$ \\
\hline & & & & $\begin{array}{c}\text { individual words } \\
\text { or sounds }\end{array}$ \\
\hline & speech but uses & $\begin{array}{c}\text { familiar and } \\
\text { unfamiliar }\end{array}$ & $\begin{array}{l}\text { forms with } \\
\text { reasonable }\end{array}$ & $\begin{array}{c}\text { features of Band } 4 \\
\text { and }\end{array}$ \\
\hline & $\begin{array}{c}\text { repetition, self- } \\
\text { correction }\end{array}$ & $\begin{array}{c}\text { topics but uses } \\
\text { vocabulary }\end{array}$ & accuracy & $\begin{array}{c}\text { some, but not all, } \\
\text { of the }\end{array}$ \\
\hline & $\begin{array}{c}\text { and/or slow } \\
\text { speech to }\end{array}$ & $\begin{array}{c}\text { with limited } \\
\text { flexibility }\end{array}$ & $\begin{array}{l}\text { - uses a limited } \\
\text { range of more }\end{array}$ & $\begin{array}{c}\text { positive features } \\
\text { of Band } 6\end{array}$ \\
\hline & keep going & $\begin{array}{c}- \text { attempts to } \\
\text { use paraphrase }\end{array}$ & $\begin{array}{c}\text { complex } \\
\text { structures, }\end{array}$ & \\
\hline & $\begin{array}{c}\text { - may over-use } \\
\text { certain }\end{array}$ & but with mixed & $\begin{array}{c}\text { but these usually } \\
\text { contain }\end{array}$ & \\
\hline & $\begin{array}{c}\text { connectives and } \\
\text { discourse }\end{array}$ & success & $\begin{array}{c}\text { errors and may } \\
\text { cause }\end{array}$ & \\
\hline & markers & & $\begin{array}{c}\text { some } \\
\text { comprehension }\end{array}$ & \\
\hline & $\begin{array}{c}\text { - produces simple } \\
\text { speech }\end{array}$ & & problems & \\
\hline & fluently, but more & & & \\
\hline & $\begin{array}{c}\text { complex } \\
\text { communication }\end{array}$ & & & \\
\hline & $\begin{array}{c}\text { causes fluency } \\
\text { problems }\end{array}$ & & & \\
\hline 4 & $\begin{array}{l}\text { - cannot respond } \\
\text { without }\end{array}$ & $\begin{array}{l}\text { - is able to talk } \\
\text { about familiar }\end{array}$ & $\begin{array}{c}\text { produces basic } \\
\text { sentence }\end{array}$ & $\begin{array}{l}\text { - uses a limited } \\
\text { range of }\end{array}$ \\
\hline & $\begin{array}{c}\text { noticeable pauses } \\
\text { and }\end{array}$ & $\begin{array}{c}\text { topics but can } \\
\text { only }\end{array}$ & $\begin{array}{c}\text { forms and some } \\
\text { correct }\end{array}$ & $\begin{array}{c}\text { pronunciation } \\
\text { features }\end{array}$ \\
\hline & $\begin{array}{c}\text { may speak slowly, } \\
\text { with }\end{array}$ & $\begin{array}{l}\text { convey basic } \\
\text { meaning on }\end{array}$ & $\begin{array}{c}\text { simple sentences } \\
\text { but }\end{array}$ & $\begin{array}{c}- \text { attempts to } \\
\text { control }\end{array}$ \\
\hline & $\begin{array}{c}\text { frequent } \\
\text { repetition and }\end{array}$ & $\begin{array}{l}\text { unfamiliar } \\
\text { topics and }\end{array}$ & $\begin{array}{c}\text { subordinate } \\
\text { structures are }\end{array}$ & $\begin{array}{c}\text { features but lapses } \\
\text { are }\end{array}$ \\
\hline & self-correction & $\begin{array}{l}\text { makes frequent } \\
\text { errors in word }\end{array}$ & rare & frequent \\
\hline & $\begin{array}{l}\bullet \text { links basic } \\
\text { sentences but }\end{array}$ & choice & $\begin{array}{c}\bullet \text { errors are } \\
\text { frequent and may }\end{array}$ & $\begin{array}{l}\bullet \\
\text { mispronunciations } \\
\text { are }\end{array}$ \\
\hline & $\begin{array}{c}\text { with repetitious } \\
\text { use of }\end{array}$ & $\begin{array}{c}\text { • rarely } \\
\text { attempts } \\
\text { paraphrase }\end{array}$ & lead to & $\begin{array}{l}\text { frequent and } \\
\text { cause some }\end{array}$ \\
\hline & $\begin{array}{c}\text { simple } \\
\text { connectives and }\end{array}$ & & misunderstanding & $\begin{array}{c}\text { difficulty for the } \\
\text { listener }\end{array}$ \\
\hline
\end{tabular}




\begin{tabular}{|c|c|c|c|c|}
\hline & some & & & \\
\hline & breakdowns in & & & \\
\hline & coherence & & & \\
\hline \multirow[t]{8}{*}{3} & $\begin{array}{c}\text { - } \text { speaks with long } \\
\text { pauses }\end{array}$ & $\begin{array}{l}\text { - uses simple } \\
\text { vocabulary to }\end{array}$ & $\begin{array}{c}\text { - attempts basic } \\
\text { sentence }\end{array}$ & $\begin{array}{c}\text { - shows some of } \\
\text { the }\end{array}$ \\
\hline & $\begin{array}{l}\text { - has limited } \\
\text { ability to link }\end{array}$ & $\begin{array}{c}\text { convey } \\
\text { personal }\end{array}$ & $\begin{array}{c}\text { forms but with } \\
\text { limited }\end{array}$ & $\begin{array}{c}\text { features of Band } 2 \\
\text { and }\end{array}$ \\
\hline & simple sentences & information & $\begin{array}{c}\text { success, or relies } \\
\text { on }\end{array}$ & some, \\
\hline & $\begin{array}{l}\text { - gives only simple } \\
\text { responses }\end{array}$ & $\begin{array}{c}\text { • has } \\
\text { insufficient } \\
\text { vocabulary }\end{array}$ & $\begin{array}{l}\text { apparently } \\
\text { memorized }\end{array}$ & $\begin{array}{c}\text { but not all, of the } \\
\text { positive }\end{array}$ \\
\hline & and is frequently & $\begin{array}{c}\text { for less familiar } \\
\text { topics }\end{array}$ & utterances & features of Band 4 \\
\hline & $\begin{array}{c}\text { unable to convey } \\
\text { basic }\end{array}$ & & $\begin{array}{c}\bullet \text { makes } \\
\text { numerous errors }\end{array}$ & \\
\hline & message & & $\begin{array}{c}\text { except in } \\
\text { memorized }\end{array}$ & \\
\hline & & & expressions & \\
\hline \multirow[t]{3}{*}{2} & $\begin{array}{c}\cdot \text { pauses lengthily } \\
\text { before most }\end{array}$ & $\begin{array}{l}\text { - only produces } \\
\text { isolated words }\end{array}$ & $\begin{array}{c}\text { - cannot produce } \\
\text { basic }\end{array}$ & - speech is often \\
\hline & words & or memorized & sentence forms & unintelligible \\
\hline & $\begin{array}{c}\bullet \text { little } \\
\text { communication } \\
\text { possible }\end{array}$ & utterances & & \\
\hline \multirow[t]{2}{*}{1} & $\begin{array}{c}\bullet \text { no } \\
\text { communication } \\
\text { possible }\end{array}$ & & & \\
\hline & $\begin{array}{c}\text { - no rateable } \\
\text { language }\end{array}$ & & & \\
\hline $\mathbf{0}$ & - does not attend & & & \\
\hline
\end{tabular}

(C) UCLES 2011. This material may be photocopied (without alteration) and distributed for classroom use provided no charge is made. For further information see our Terms of Use at www.teachers.cambridgeesol.org/ts/terms Assessing speaking IELTS www.teachers.cambridgeesol.org

\section{Appendix (2)}

\section{WorldView}

Video/DVD Speaking Rubric

Speaking rubric for fluency activities

Rating:

Name:

Activity:

WV Level / Segment:

Comments: 


\begin{tabular}{|c|c|}
\hline Rating & Demonstrated competence \\
\hline 4 & $\begin{array}{l}\text { - Uses a variety of vocabulary and expressions } \\
\text { - Uses a variety of structures with only occasional grammatical errors } \\
\text { - Speaks smoothly, with little hesitation that does not interfere with } \\
\text { communication } \\
\text { - Stays on task and communicates effectively; almost always responds } \\
\text { appropriately and always tries to develop the interaction } \\
\text { - Pronunciation and intonation are almost always very } \\
\text { clear/accurate }\end{array}$ \\
\hline 3 & $\begin{array}{l}\text { - Uses a variety of vocabulary and expressions, but makes some errors in } \\
\text { word choice } \\
\text { - Uses a variety of grammar structures, but makes some errors } \\
\text { - Speaks with some hesitation, but it does not usually interfere with } \\
\text { communication } \\
\text { - Stays on task most of the time and communicates effectively; } \\
\text { responds appropriately and keeps trying to develops the interaction } \\
\text { - Pronunciation and intonation are usually clear/accurate with a few } \\
\text { problem areas }\end{array}$ \\
\hline 2 & $\begin{array}{l}\text { - Uses limited vocabulary and expressions } \\
\text { - Uses a variety of structures with frequent errors, or uses basic structures } \\
\text { with only occasional errors } \\
\text { - Speaks with some hesitation, which often interferes with communication } \\
\text { - Tries to communicate, but sometimes does not respond appropriately } \\
\text { - Pronunciation and intonation errors sometimes make it difficult to } \\
\text { understand the student }\end{array}$ \\
\hline Rating & Demonstrated competence \\
\hline 1 & $\begin{array}{l}\text { - Uses only basic vocabulary and expressions } \\
\text { - Uses basic structures, makes frequent errors } \\
\text { - Hesitates too often when speaking, which often interferes with } \\
\text { communication } \\
\text { - Purpose isn't clear; needs a lot of help communicating; usually doesnot } \\
\text { respond appropriately or clearly } \\
\text { - Frequent problems with pronunciation and intonation }\end{array}$ \\
\hline
\end{tabular}

Adapted from Authentic Assessment for English Language Learners by J. Michael O'Malley and Lorraine Valdez Pierce, Addison-Wesley Publishing Company. Video/DVD Speaking Rubric for Fluency Activities, 2005 by Pearson Education, Inc. Permission granted to reproduce for classroom use e. 


\section{References}

- Abeysekera, L. \& Dawson, P. (2015). Motivation and cognitive load in the flipped classroom: Definition, rationale and a call for research. Higher Education Research \& Development, 34(1), 1-14.

- Abu Bakar, A., Abidin, N., Ali, Z., Isa, N. \& Sahar, N., (2018). Exploring the use of flipped learning approach in teaching grammar. Proceeding: International Academic Conference, 103-106. Batu Ferringhi, Penang, Malaysia,

- Akcayir, G.,\& Akcayir, M. (2018). The flipped classroom: A review of its advantages and challenges. Computers \& Education, 126 (1), 334-345.

- Al-Harbi, S. \& Alshumaimeri, Y. (2016). The flipped classroom impact in grammar class on EFL Saudi secondary school students' performance and attitude. English Language Teaching, 9 (10), 60- 80.

- AlKhoudary, Y. A., \& AlKhoudary, J. A. (2019). The effectiveness of flipping classroom model on EFL secondary school speaking skills. Indonesian EFL Journal, 5(2), 1-10.

- Alsowat, H. (2016). An EFL flipped classroom teaching mode: Effects on English language higher-order thinking skills, student engagement and satisfaction. Journal of Education and Practice, 7(9), 108-121.

- Alvarez, B. (2011). Flipping the Classroom: Homework in Class, Lessons at Home. Education Digest: Essential Readings Condensed For Quick Review, 77, $18-21$.

- Al-zahrani, A. (2015). From passive to active: the impact of the flipped classroom through social learning platform on higher education students' creative thinking. British Journal of Educational Technology, 46, (6), 11331148 .

- Baker, J. W. (2000). The 'classroom flip': Using web course management tools to become the guide by side. Paper presented at the 11th International Conference on College Teaching and Learning, Jacksonville, FL.

- Bassal, A (2015). The implementation of a flipped classroom in foreign language teaching. Turkish Online Journal of Distance Education, 16(4), 28- 37. 
- Baepler, P., Walker, J., \& Driessen, M. (2014). It's not about seat time: Blending, flipping, and efficiency in active learning classroom. Computers and Education, 78, 227- 236.

- Bergmann, J., \& Sams, A. 2012, "Flip your classroom: Reach every student in every class every day". Alexandria, VA: International Society for Technology in Education.

- Bishop, L. J. 2013, "A Controlled Study of the Flipped Classroom with Numerical Methods for Engineers". Unpublished Doctoral Thesis, Engineering Education of Utah State University, Logan, Utah, USA.

- Bishop, J. \& Verlager, M. A. (2013). The flipped class-room: a survey of the research. Paper presented at 120th ASEE Annual Conference \& Exposition, Atlanta, USA.

- Bohota, N. (2019). Flipped Classroom: Teaching and Learning of English Language in the Context of EFL. Unpublished MA thesis, BRAC Institute of Languages (BIL) Brac University: Dhaka, Bangladesh.

- Brunsell, E., \& Horejsi, M. (2013). A flipped classroom in action. The Science Teacher, 80(2), 8.

- Calimeris, L., \& Sauer, K. M. (2015). Flipping out about the flip: All hype or is there a hope? International Review of Economics Education, 20, 13-28.

- Chilingaryan, K.\& Zvereva, E. (2017). Methodology of flipped classroom as a learning technology in foreign language teaching. Procedia - Social and Behavioral Sciences, 237, 1500- 1504.

- Clark, K. (2015). The effects of the flipped model instruction on student engagement \& performance in the secondary mathematics classroom. Journal of Educators Online, 12(1), 91-115.

- Correa, M. (2015). Flipping the foreign language classroom and critical pedagogies: a (new) old trend. Higher Education for the Future, 2(2), 114-125.

- Desouky, E. (2019). The effects of flipped learning approach on FL Egyptian learners to reinforce study of English. JRCIET, 5 (3), 135- 161.

- Dewey, J. (2013). My pedagogical creed. In D. J. Flinders, \& S. J. Thornton (Eds.), The Curriculum Studies Readers (p. 36). New York, NY: Routledge. 
- Doman, E., \& Webb, M. (2017).The Flipped Experience for Chinese University Students Studying English as a Foreign Language. TESOL Journal, 8(1),102141.

- Dweikat, k., \& Raba, A. (2019). English as a Foreign Language (EFL) Teachers' Perceptions of Flipped Classroom Model in Palestine. IUG Journal of Educational and Psychological Sciences,27(3), 29-47.

- Educause. (2012). 7 Things You Should Know About Flipped Classrooms. Learning Initiative (ELI).

- Ekmekci, E. (2017). The flipped writing classroom in Turkish EFL context: A comparative study on a new model. Turkish Online Journal of Distance Education, 18 (2), 18- 20.

- Engin, M. 2014, "Extending the flipped classroom model: Developing second language writing skills through student-created digital videos". Journal of the Scholarship of Teaching and Learning, 14 (5), $12-26$.

- Eryaman, M. Y., \& Genc, S. (2010). Learning theories. In C. Kridel (Ed.), The Sage encyclopedia of curriculum studies (pp. 534-537). Thousand Oaks, CA: Sage.

- Evseeva, A., \& Solozhenko, A. (2015). Use of flipped classroom technology in language learning. XV 44 International Conference "Linguistic and Cultural Studies: Tradition and Innovation", LKTI, Russia. Procedia - Social and Behavorial Sciences, 206, 205- 209.

- Fulton, K. (2012). Upside down and inside out: flip your classroom to improve student learning. Learning \& Leading with Technology, 39(8), 12-17.

- Gannod, G. C. 2007, "Work in progress: Using podcasting in an inverted classroom". Paper presented at Annual Frontiers in Education Conference, Milwaukee, WI.

- Goodwin, B., \& Miller, K. (2013). Research says / evidence on flipped classrooms is still coming in. Technology-Rich Learning, 70(6), 78-80.

- Graham, E., \& Walker, T. (2013).What 'Flipped' classrooms can (and can't) do for education. National Education Association Today, neatoday.org. 
- Green, R. D., \& Schlairet, M. C. (2016). Moving toward heutagogical learning: Illuminating undergraduate nursing students' experiences in a flipped classroom. Nurse Education Today, 49, 122-128.

- Hamdan,N.,McKnight,P.,McKnight,K.,\&Arfstrom,K.M.(2013). The Flipped Learning Model: A White Paper Based on the Literature Review. Pearson. George Mason University.

- Harris, J. (2016). Flipping the undergraduate economics classroom: Using online videos to enhance teaching and learning. Southern Economic Journal, 83(1), 321- 331.

- Hashemifardnia, A., Namaziandost, E., \& Shafiee, S. (2018). The effect of implementing flipped classrooms on Iranian junior high school students' reading comprehension. Theory and Practice in Language Studies, 8 (6), 665-673.

- Hongwei Zhang, Xiaomei Du, Xinfa Yuan, Liming Zhang. (2016).

- The Effectiveness of the Flipped Classroom Mode on the English Pronunciation Course. Creative Education, 7, 1340-1346.

- Hung, H. T. (2015). Flipping the classroom for English language learners to foster active learning. Computer Assisted Language Learning, 28(1), 81-96.

- Johnson, G. (2013). Student Perceptions of the Flipped Classroom. Unpublished MA thesis, University of British Colombia: Okanagan.UBCO.

- Kim, M., Kim, S., Khera, O.,\& Getman, J. (2014). The experience of three flipped classrooms in an urban university: An exploration of design principles. The Internet and Higher Education, 2, 37- 50.

- Knight, M. (2016). Flipped classrooms and discovery learning in business and professional communication. Communication Quarterly, 79(1), 3-5.

- Koroglu, Z., \& Cakir, A. (2017). Implementation of flipped instruction in language classrooms: An alternative way to develop speaking skills of preservice English language teachers. International Journal of Education and Development using Information and Communication Technology (IJEDICT), $13(2), 42-55$. 
- Lage, M. J., Platt, G. J., \& Treglia, M. 2000, "Inverting the classroom: A gateway to creating an inclusive learning environment". The Journal of Economic Education, Vol. 31, No.1, pp. 30-43.

- Li, S. \& Suwanthep, J., (2017). Integration of Flipped Classroom Model for EFL Speaking. International Journal of Learning and Teaching, 3 (2), 118- 123.

- McLaughlin, J, et al. (2014). The flipped classroom: A course redesign to foster learning and engagement in a health professions school. Academic Medicine, 89 (2), 236- 243.

- Millard, E. (2012). Five reasons flipped classrooms work: Turning lectures into homework to boost student engagement \& increase technology-fueled creativity. University Business, 15(11), 26-29.

- Missildine, K., et al. (2013). Flipping the classroom to improve student performance and satisfaction. Journal of Nursing Education, 52 (1), 597- 599.

- Morgan, H. (2014). Focus on technology: Flip your classroom to increase academic achievement. Childhood Education, 90(3), 239-241.

- Nanclares, N. H., \& Rodríguez, M. P. (2016). Students' satisfaction with a blended instructional design: The potential of "Flipped Classroom" in Higher Education. Journal of Interactive Media in Education, 1(4), 1-12.

- Newman, G., Kim, J., Lee, R. J., Brown, B. A., \& Huston, S. (2016). The perceived effects of flipped teaching on knowledge acquisition. The Journal of Effective Teaching, 16(1), 52-71.

- Obari, H., \& Lambacher, S. (2015). Successful EFL teaching using mobile technology in a flipped classroom. In Proceedings of the 2015 EUROCALL Conference (pp. 433-438). Padova, Italy.

- Osguthorpe, R. T., \& Graham, C. R. 2003, "Blended learning environments: Definitions and directions". Quarterly Review of Distance Education, 4 (3), 227-233.

- Plasencia, A. (2014). MOOCs, the flipped classroom, and Khan Academy practices: The implications of augmented learning. Innovation and Teaching Technologies, Springer, New York. pp. 1- 10. 
- Qader, R. \& and Arslan, F. (2019). The effect of flipped classroom instruction in writing: A case study with Iraqi EFL learners. Teaching English with Technology, 19(1), 36- 55.

- See, S., \& Conry, J. (2014). Flip my class! A faculty development demonstration of a flipped-classroom. Currents in Pharmacy Teaching and Learning, 6(4), 585-588.

- Shotaro, A., Fumiya, S. \& Haruya, Y. (2018). The Effect of a Flipped Classroom Approach on EFL Japanese Junior High School Students' Performances and Attitudes. International Journal of Heritage, Art and Multimedia, 1 (3), 71-87.

- Shuangjiang, L. \& Suwanthep, J. (2017). Integration of Flipped Classroom Model for EFL Speaking. International Journal of Learning and Teaching, 3(2), 118-123.

- Singh, C., Singh, H.,Singh, T., Ja'afar, H., Abdullah, M., Mostafa, N., and Zamri, M. (2018). Flipped classroom approach for improving speaking skills of TVET trainees. International Journal of Applied Linguistics \& English Literature, 7 (7), 27- 39.

- Sletten, S. (2015). Investigating Flipped Learning: Post-Secondary Student SelfRegulated Learning, Perceptions, and Achievement. Unpublished Ph.D. dissertation, University of North Dakota: Grand Forks.

- Snowden, E. K. 2012, "Teacher Perceptions of the Flipped Classroom: Using Video Lectures Online To Replace Traditional In-Class Lectures". Unpublished MA Thesis, University of North Texas, Texas, USA.

- Soliman, N. A. (2016). Teaching English for academic purposes via flipped learning approach. Procedia - Social and Behavioral Sciences, 232,122-129.

- Stone, B. B. (2012). Flip your classroom to increase active learning and student engagement. Proceedings of International Annual Conference on Distance Teaching \& Learning. WI: Madison.

- Strayer, J. 2007, "The Effects of the classroom Flip on the Learning Environment: a comparison of learning activity in a traditional classroom and a flip classroom that used an intelligent tutoring system". Unpublished Doctoral Dissertation, Ohio State University, Ohio, USA. 
- Strayer, J. F. (2012). How Learning in an Inverted Classroom Influences Cooperation, Innovation and Task Orientation. Learning Environments Research, 15, 171-193.

- Sung, K. (2015). A case study on a flipped classroom in an EFL content course. Multimedia - Assisted Language Learning, 18(2), 159-187.

- Torkelson, V. (2012). The flipped classroom, putting learning back into the hands of students. Unpublished Ph.D. dissertation, Saint Mary's College of California: Moraga, CA.

- Toto, R., \& Nguyen, H. (2009). Flipping the work design in an industrial engineering course. Paper presented at the 39th ASEE/IEEE Frontiers in Education Conference, San Antonio, TX.

- Tucker, B. (2012). The Flipped classroom: Online instruction at home frees class time for learning. Education Next, 12(1), 82-83.

- Vaezi, R., Afghari, a., \& Lotfi, A. (2019). Investigating listening comprehension through flipped classroom approach: Does authenticity matter? CALL-EJ, 20(1), 178-208.

- Velegol, S. , Zappe. , \& Mahoney, E. (2015). The evolution of a flipped classroom: Evidence-based recommendations. Advances in Engineering Education, 4 (3), 1- 37.

- Wang, X. D., \& Zhang, C. J. Z. (2013). The Application Research of Flipped Classroom in University Teaching _ A Case Study on Professional English of Educational Technology. Modern Educational Technology, 23, 11-16

- Webb, M., \& Doman, E. (2016). Does the Flipped Classroom Lead to Increased Gains on Learning Outcomes in ESL/EFL Contexts? The CATESOL Journal, 28 (1), 39- 67.

- Wu, W., Hsieh, J., \& Yang, J. (2018). Personalizing Flipped Instruction to Enhance EFL Learners' Idiomatic Knowledge and Oral Proficiency. Learning, Design, and Technology: An International Compendium of Theory, Research, Practice, and Policy.1-23. 
- Yaman, I. 2014, "ELT Students' Attitudes towards the Development of Speaking Skills via Project-Based Learning: an Omnipresent Learning Perspective". Unpublished Ph.D. dissertation, Gazi University, Ankara, Turkey.

- Yang, J. J. (2016). Flipped Classroom Model Based on Micro-Lecture-Taking Phonology Class of English Majors as an Example. Journal of Shandong Yingcai University, 12, 23-25.

- Yavuz, F. \& Ozdemir, S. (2019). Flipped classroom approach in EFL context: Some associated factors. World Journal on Educational Technology: Current Issues. 11(4), 238-244.

- Yeşilçınar, S. (2019). Using the Flipped Classroom to Enhance Adult EFL Learners' Speaking Skills. PASAA, 58, 206-234.

- Yu, Z., \& Wang, G. (2016). Academic achievement and satisfaction of the clicker-aided flipped business English writing class. Journal of Educational Technology \& Society, 19 (2), 298- 312.

- Zainuddin, Z., \& Halili, S. H. (2016). Flipped classroom research and trends from different fields of study. International Review of Research in Open and Distributed Learning, 17(3), 313-340.

- Zakareya, S. \& Alahmad, S. (2019). Inverted Teaching for Improving the Teaching Performance of EFL Student Teachers at Jubail College of Education. English Language Teaching, 12 (4), 15-20.

- Zhang, P., Ma, J., \& Liu, Y. (2014). Flipped classroom: An effective model of improving student teachers' educational technology. Journal of Information Technology \& Application in Education, 3(3), 144-149.

- Zhang, H, Du, X, Yuan, X, \& Zhang, L. (2016). The effectiveness of the flipped classroom model on the English pronunciation course. Creative Education, 7 (9), 1340- 1346.

- Zhuochao, J. (2017). To Flip or Not? Deciding on Whether to Use a Flipped Classroom Approach With of Higher-Level Second Language Students. Unpublished MA thesis, University of Victoria: Canada. 